\title{
THE SUPREME COURT'S LAST 30 YEARS OF FEDERAL INDIAN LAW: LOOKING FOR EQUILIBRIUM OR SUPREMACY?
}

\author{
By Alexander Tallchief Skibine*
}

For 187 years, Indian nations status in the United States has not been fully developed or consistently approached within the law. They are viewed as Domestic Dependent Nations located within the geographical boundaries of the United States. Although Chief Justice John Marshall acknowledged that Indian nations had a certain amount of sovereignty, the exact extent of such sovereignty as well as the place of tribes within the federal system has remained illdefined. This Article examines what has been the role of the Supreme Court in integrating Indian nations as the third Sovereign within our federalist system. The Article accomplishes this task by examining the Court's Indian law record in the last 30 years. The comprehensive survey of Indian law decisions indicates that while the tribal win-loss record at the Supreme Court is improving, the Court has had difficulties upholding the federal policy of respecting tribal sovereignty and encouraging tribal self-government.

After categorizing the cases between victories and losses, the Article divides the cases into categories for analytical purposes. The Second half of the Article focuses on the interaction between the Court and Congress concerning the incorporation of tribes as the third sovereign within the federalist system, and ends by arguing that through its

\footnotetext{
* Alexander Tallchief Skibine is the S.J. Quinney Professor of Law, University of Utah S.J. Quinney College of Law. B.A. Tufts University; J.D. Northwestern University School of Law. The author would like to thank Professor Kirsten Carlson for providing critical comments and suggestions on a previous draft of this Article. This research was made possible, in part, through generous support from the Albert \& Elaine Borchard Fund for Faculty Excellence.
} 
disproportionate use of federal common law in its Indian law decisions, the Court has not attempted to reach a consensus with Congress about the place of Indian nations within our federalism.

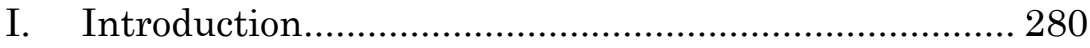

II. The Court's Record in The Last Thirty Years. ........... 285

A. The Record When Cases are Divided According to Subject Matter......................................................... 286

1. Sovereign/Political rights: 38.5 cases. ................ 287

2. Economic/property rights: 14.5 cases. ................. 289

3. Rights derived from the Federal-trust relationship:

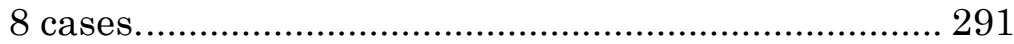

4. Cultural/Religious Rights: 3 cases...................... 292

B. The Record Based on the Type of Law Used to Decide the Cases......................................................................... 293

1. Federal Common law decisions: 28.5 cases.......... 294

2. Statutory Interpretation cases: 21.5 cases.......... 297

3. Constitutional Law: 11 cases. .............................. 299

4. Administrative/Civil Procedure Law: 5 cases. ..... 302

C. The Record When the Cases Are Considered along Time

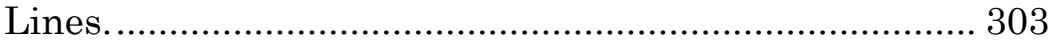

III. Looking for Equilibrium or Judicial Supremacy?... 305

A. Evaluating Congressional Response to The Court's Decisions. 305

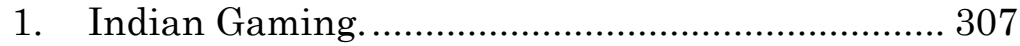

2. Tribal Criminal Jurisdiction over non-Indians and non-member Indians................................................ 308

3. Indian land Consolidation Act: ............................ 309

4. Overturning Patchak:....................................... 310 
5. Overturning Employment Division v. Smith. ...... 310

6. Responding to Lyng v. Northwest Indian Cemetery. 311

B. Evaluating the Court's Reaction to Federal Legislation. 313

1. Interpreting the Indian Gaming Regulatory Act

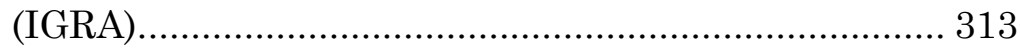

2. Interpreting the Alaska Native Claims Settlement Act (ANCSA). 314

3. Interpreting Indian Child Welfare Act (ICWA). .. 315

4. Interpreting Section 5 of the Indian Reorganization Act (IRA). 315

5. Indian Land Consolidation Act............................ 316

6. Interpreting the Indian Self Determination Act. . 317

C. The Road Not Taken 318

1. Tribal civil jurisdiction over non-members: 318

2. Pre-empting state tax jurisdiction in Indian Country. 320

3. Enacting a Seminole fix. 321

4. Recognizing Native Hawaiians. 322

5. Overturning Carcieri v. Salazar. 322

6. Repealing Section 5 of the Indian Reorganization Act (IRA) or declaring it unconstitutional... 323

7. Abrogating tribal Sovereign Immunity 323

8. Amending the Indian Child Welfare Act (ICWA) or declaring it unconstitutional. 325

D. Looking for A Different Kind of Equilibrium Through the Use of Federal Common Law. 326

IV. Conclusion 333

V. Appendix A 335 


\section{INTRODUCTION}

Since 1831, Indian nations have been viewed as Domestic Dependent Nations located within the geographical boundaries of the United States. ${ }^{1}$ Chief Justice Marshall attributed that status to the fact that Indian tribes had signed treaties in which they acknowledged themselves to be under the protection of the United States, ${ }^{2}$ the fact that Indian nations were understood to be within the geographical boundaries of the United States, ${ }^{3}$ and the description of Indian nations as "tribes" and not "foreign nations" within the structure of the Constitution. ${ }^{4}$ Although Chief Justice Marshall acknowledged that Indian nations had a certain amount of sovereignty, ${ }^{5}$ the exact extent of such sovereignty, as well as the place of tribes within the federal system, has remained ill-defined. Although the Constitution arguably acknowledged the sovereign status of Indian Nations, ${ }^{6}$ the

${ }^{1}$ Cherokee Nation v. Georgia, 30 U.S. 1, 17 (1831). Although this Article will use the terms "Indian nations" and "Indian tribes" interchangeably, the United States Constitution refers only to Indian "tribes." The use of the term "tribes" in the Constitution played a key role in Cherokee Nation $v$. Georgia where the Court held that Indian tribes were neither States of the Union nor foreign nations for the purpose of invoking the original jurisdiction of the Supreme Court under the Constitution.

2 See Alex T. Skibine, Redefining the Status of Indian Tribes within "Our Federalism": Beyond the Dependency Paradigm, 38 ConN. L. REV. 667, 695 (2006), and Alex T. Skibine, United States v. Lara, Indian Tribes, and the Dialectic of Incorporation, 40 TULSA L. REV. 47, 70 (2004).

${ }^{3}$ Relying on the doctrine of discovery as enunciated in Johnson $v$. M'Intosh, 21 U.S. 543, 605 (1823).

${ }^{4}$ See U.S. Const. art. I., § 8, cl. 3 (the Commerce Clause): "Congress shall have the power the power to regulate commerce among the States, with the foreign Nations, and with the Indian tribes".

5 Worcester v. Georgia, 31 U.S. 515, 557 (1832) (stating that Indian nations had "territorial boundaries within which their authority is exclusive."). For an in-depth analysis of Justice Marshall's opinion, see Philip P. Frickey, Marshalling Past and Present: Colonialism, Constitutionalism, and Interpretation in Federal Indian Law, 107 HARV. L. REV 381, 440 (1993).

${ }^{6}$ As stated by one scholar "[a]s a textual matter the Constitution does recognize tribal sovereignty in the Commerce Clause and the Treaty Clause." Ann E. Tweedy, Connecting the Dots between the Constitution, the 
exact nature of that sovereignty is neither described nor protected in the Constitution. ${ }^{7}$

Initially, the Supreme Court deferred questions concerning the status of Indian tribes within the political system of the United States to Congress, ${ }^{8}$ whose policy towards Tribes changed with the times. ${ }^{9}$ At first, Indian nations were viewed as political entities existing outside of the U.S. political system, and most of the relations between the United States and the Tribes were governed through treaties. ${ }^{10}$ Things began to change after 1871 , when a law was enacted to prohibit the execution of any additional treaties with Indian nations. ${ }^{11}$ Soon after, the United States embarked on a policy aimed at assimilating individual Indians into the mainstream American society. ${ }^{12}$ There was no attempt to integrate Indian nations into the U.S. political system as sovereign governments, and the expectation was that Indian tribes, as political entities, would soon disappear. ${ }^{13}$ However, in the 1930s Congress changed course and made the decision to integrate tribes into the U.S. political system as quasi-sovereign entities. ${ }^{14}$ The current policy of the United States is to promote tribal self-determination and recognize Tribes as self-governing entities with enough

Marshall's Trilogy, and Tribal Sovereignty, 42 U. Mich. J. L. RefoRm 651, 655-64 (2009).

${ }^{7}$ United States v. Lara, 541 U.S. 193, 219 (2004) (Thomas, J., concurring) ("The Tribes, by contrast, are not part of this constitutional order, and their sovereignty is not guaranteed by it.").

${ }^{8}$ See, e.g., United States v. Kagama, 118 U.S. 375, 385 (1886); Lone Wolf v. Hitchcock, 187 U.S. 553, 568 (1903) (holding that congressional decisions in the management of tribal property was a political question).

${ }^{9}$ See Felix Cohen, Handbook of Federal Indian LaW 23-108 (2012 ed.).

${ }^{10}$ See Vine Deloria Jr., Reserving to Themselves: Treaties and the Powers of Indian Tribes, 38 ARIz. L. REV. 963, 979 (1996).

${ }^{11}$ Act of March 3, 1871, 16 Stat. 466 (1871) (codified as amended at 25 U.S.C. 71 (2000) ("No Indian nation of tribe within the territory of the United States shall be acknowledged or recognized as an independent nation, tribe, or power with whom the United States may contract by treaty.")

${ }^{12}$ See Cohen, supra note 9, at 71-79.

${ }^{13}$ See Kathryn E Fort, The Vanishing Indian Returns: Tribes, Popular Originalism, and the Supreme Court, 57 ST. LoUIS U. L. J. 297 (2013).

${ }^{14}$ See Cohen, supra note 9, at 79-84. 
sovereignty to have a government-to-government relationship with the United States. ${ }^{15}$ This Article examines the role of the Supreme Court in integrating Indian nations as the Third Sovereign within the U.S. federalist system. ${ }^{16}$

Although the author has written about similar topics in the past, ${ }^{17}$ this Article looks at the role of the Court by surveying and examining the Court's Indian law record in the last thirty years. The Supreme Court's record of decided cases in the last thirty years indicates that the Court has had difficulties upholding the federal policy of respecting tribal sovereignty and encouraging tribal self-government. In an influential article, David Getches documented that during the first fifteen terms of the Rehnquist Court, Indian tribal interests only won approximately twenty-three percent of federal Indian law cases at the Supreme Court from 1986 until 2001. ${ }^{18}$ As the title of his article indicated, Getches believed that the dismal tribal record was influenced by the Court's agenda to promote states' rights, a color-blind agenda, and mainstream values.

Getches's findings were later supplemented by Matthew Fletcher who analyzed the Cert process at the Supreme Court and found that while very few tribal petitions were granted, a disproportionately large number of petitions filed by non-tribal interests aimed at overturning decisions favorable to these tribal interests were granted. ${ }^{19}$ In a more recent article, Bethany Berger updated the numbers found by Getches by looking at cases decided between 1990 and $2016 .{ }^{20}$

15 See Matthew L.M. Fletcher, The Supreme Court and Federal Indian Policy, 85 NeB. L. REV. 121, 135-36 (2006).

${ }^{16}$ Describing Indian nations as "the Third Sovereign" may have originated with Justice O'Connor. See Justice Sandra Day O'Connor, Lessons from the Third Sovereign: Indian Tribal Courts, 33 TULSA L.J. 1, 6 (1997).

17 See Skibine, supra note 2

18 David H. Getches, Beyond Indian Law: The Rehnquist Court's Pursuit of States' Rights, Color-Blind Justice and Mainstream Values, 86 MinN. L. REV. 267, 280-81 (2001).

${ }^{19}$ Matthew L.M. Fletcher, Factbound and Splitless: The Certiorari Process as Barrier to Justice for Indian Tribes, 51 ARIz. L. REV. 933, 981 (2009).

20 Bethany Berger, Hope for Indian Tribes in the U.S. Supreme Court, Menominee, Nebraska v. Parker, Bryant, Dollar General, 2017 U. ILL. L. REV. 1901, 1943 (2017) (Hereinafter "Hope for Indian Tribes"). 
While confirming that the percentage of tribal wins from 1990 until 2015 had not improved since Getches's 2001 article, she saw an improvement in the 2015-2016 term that perhaps indicated that tribal interests could find some light at the end of this anti-tribal judicial tunnel.

This article begins with an in-depth examination of the last thirty years of Indian law decisions. ${ }^{21}$ Starting where Berger left off, after first categorizing the cases between victories and losses during this time, Part II divides the cases into four general areas within the field of federal Indian law: Political/Sovereign Rights, Economic Rights (treaty/property rights), Rights derived from the Indian trust doctrine, and Cultural/Religious Rights. The cases are then further divided into four categories: federal common law, statutory interpretation, constitutional law, and procedural law. Appendix A lists all the cases in chronological order and also identifies the areas of law and the type of law used to decide each case. Part II ends by assessing the trends in the evolution of the cases and concludes by formulating general principles that can be derived from the tribal win/loss record in these different classifications.

Part III focuses on the dialectic between the Court and Congress concerning the incorporation of tribes as third sovereigns within the federalist system. First, it evaluates Congress's response to Supreme Court cases. Second, it examines at the Court's response to congressional legislation. In a noted article, Philip Frickey and William Eskridge argued that when deciding cases, the Court evaluates what Congress and the executive branch think about the broader issues involved in such cases and responds accordingly, in effect trying to reach a legal "equilibrium" amongst the three branches of government. As stated by the authors:

Positive political theory claims that lawmaking institutions are rational, self-interested,

${ }^{21}$ My survey starts with the 1987-1988 term and ends with the 2016-2017 term. For another survey, see Lawrence R. Baca, 40 Years of U.S. Supreme Court Indian Law Cases, 62 APR FED. LAW 18, 30 (2015) (listing all the cases from 1976 until 2014, classifying them as tribal victories or not, and commenting on the Justices who wrote some of the cases). 
interdependent, and affected by the sequence of institutional interaction. When viewed through this lens, law is ... an equilibrium, a state of balance among competing forces or institutions. Congress, the executive, and the courts engage in purposive behavior. Each branch seeks to promote its vision of the public interest... To achieve its goals, each branch also acts strategically, calibrating its actions in anticipation of how other institutions would respond. ${ }^{22}$

Yet when it comes to federal Indian law, one has to wonder if the Supreme Court does not have another agenda. One that does not try to reach an equilibrium with the other two branches of the government about incorporating tribes as the third sovereign within our federalism, but instead aims to impose the Court's own terms for how Indian tribes should be integrated into the system.

As asserted by Judith Resnick, when issues become important enough to the government, it will remind "the dominated group of its dependence upon the larger collective and works to bring the smaller group into compliance with federal norms." ${ }^{23}$ Federal courts will impose federal rules of decisions on either state or tribal courts. ${ }^{24}$ Although most tribes used to be isolated geographically and lacked the financial resources to have much of an impact on the nonIndian world, their access has evolved in the last thirty years. Tribes are now meaningful actors, both economically and politically. This could explain the Court's new aggression in taking on Indian cases and, some may argue, judicial activism in modifying foundational principles that were established when Tribes were not much of a factor in the economic and

${ }^{22}$ See William N. Eskridge \& Philip P. Frickey, Law as Equilibrium, 108 HARV. L. REv. 26, 28-29 (1994).

${ }^{23}$ Judith Resnick, Dependent Sovereigns: Indian Tribes and the Federal Courts, 56 U. CHI. L. Rev. 671, 756 (1989).

${ }^{24} I d$. at 754 (stating that federal courts have allowed Tribes unrestricted authority on certain intra tribal issues such as tribal membership dispute because these "are not decisions of national importance.") 
political life of the United States. ${ }^{25}$ This may be the reason for what Frickey's observation the Court was in the process of "flattening" federal Indian law into the broader American public law by importing general constitutional and subconstitutional value into the field. ${ }^{26}$

Some scholars contend that Congress has relinquished its leading role in formulating federal Indian policy. ${ }^{27}$ Others argue that Congress is in fact much more active in enacting laws affecting or concerning Indian nations than previously thought. ${ }^{28}$ Part III concludes by evaluating the role of the Court's use of federal common law, arguing that the Court is not trying to reach an equilibrium with Congress but is looking for a different kind of equilibrium. In other words, the Court is not attempting to achieve a balance between Congress and itself, but is aiming to establish what the Court perceives should be the proper equilibrium between tribal interests and the non-Indian/state interests.

\section{THE COURT's RECORD IN THE LAST THIRTY YEARS.}

As reflected in Appendix A, the survey takes into account sixty-six cases. ${ }^{29}$ The survey shows that of these

\footnotetext{
25 On foundational principles of federal Indian law and how the Court is changing them, see David H. Getches, Conquering the Cultural Frontier: The New Subjectivism of the Supreme Court in Indian Law, 84 CAL L. REV. 1573, 1655 (1996).

${ }^{26}$ Philip P. Frickey, A Common Law for Our Age of Colonialism: The Judicial Divestiture of Indian Tribal Authority over Non-Members, 109 YALE L.J. 1, 73-77 (1999).

27 See Fletcher, Federal Indian Policy, supra note 15.

28 See Kirsten Matoy Carlson, Congress and Indians, 86 U. CoLO. L. REV. 77 (2015).

29 Not included in the total number of cases is South Florida Water Management District v. Miccosukee Tribe of Indians, 541 U.S. 95 (2004). The case involved an Indian tribe and a number of environmental organizations bringing a case against a Florida water management district for violation of the Clean Water Act. The case was remanded for more factual findings. I do not regard this case as a federal Indian law case. It is an environmental law case where one of the plaintiffs happened to be an Indian tribe. I have also not included Department of the Interior v. South Dakota, 117 S. Ct. 286 (1996). The case involved a challenge to the Interior
} 
sixty-six cases, tribal interests lost forty-seven and a half cases and won eighteen and a half cases. ${ }^{30}$ This represents a tribal win/loss ratio of only $28 \%$. However, that percentage is higher than the number reported by Getches in his 2001 study $(23 \%),{ }^{31}$ and slightly higher than the percentage reported by Berger in her more recent study. ${ }^{32}$

After much debate, I decided to include Dollar General v. Mississippi Choctaw ${ }^{33}$ as a tribal win although, perhaps, the case is better described as not-a-loss rather than an outright win: The Supreme Court split 4-4 thereby affirming the decision below that was in favor of tribal civil jurisdiction over a non-member. However, judicial experts seem to agree that if Justice Scalia had still been alive, his previous record and questioning during the oral argument indicate that, in all likelihood, he would have voted against the tribal interests. ${ }^{34}$

\section{A. The Record When Cases are Divided According to Subject Matter.}

In this section, the cases are classified according to four subject matter areas that affect tribal rights: Sovereign/Political Rights, Economic/Property Rights, Rights derived from the Trust Relationship, and Cultural/Religious

Secretary's decision to take land in trust for a Tribe. Without issuing a substantive opinion, the Court just issued a GVR. This meant the Court granted cert, vacated the decision below, and ordered the case remanded to the Secretary (GVR) so that a new decision could be made using newly issued departmental regulations.

30 The half point comes from the fact that in Brendale v. Confederated Tribes, 492 U.S. 408 (1990), the Tribe won half the case (tribal jurisdiction over non-member property in the "closed" part of the reservation), but lost the other half of the case (no tribal jurisdiction over non-member property in the "open" section).

${ }^{31}$ See Getches, Beyond Indian Law, supra note 18.

32 See Berger, Hope for Indian Tribes, supra note 20. Berger's percentage of tribal wins from 1990 until 2016 is $27.3 \%$. The minor difference can be explained by the slightly different scope of the years covered in the two surveys. Her count is based on years, 1990-2016, while mine is based on Supreme Court terms, from the 1987-88 term until the 2016-17 term. The difference in the times covered results in a difference in the number of cases considered: fifty-three in her study, sixty-six for this study.

33 Dollar General v. Mississippi Band of Choctaw, 136 S. Ct. 2159 (2016).

${ }^{34}$ See Berger, Hope for Indian Tribes, supra note 20, at 1936. 
Rights. Sixty-four ${ }^{35}$ of the sixty-six total cases identified were considered for categorization based on subject matter.

\section{Sovereign/Political rights: 38.5 cases.}

This category concerns cases involving the sovereign rights of Indians tribes, either to assume jurisdiction over nonmembers, or claim sovereign immunity when being sued in state or federal court. Most of the cases decided by the Court concerning tribal interests involve, in some manner or another, the political or sovereign rights of the tribes, thus this category contains thirty-eight and a half out of sixty-six cases, making it the largest category. ${ }^{36}$ The category also concerns the sovereign rights of states to assume jurisdiction in Indian Country, or claim sovereign immunity when being sued by Tribes, and a few cases involving the application of the Indian Child Welfare Act. Because this Article deems one case as being half a loss and half a win for the Tribes, ${ }^{37}$ the record indicates that tribal interests suffered twenty-six and a half losses while winning twelve cases (31.1\%).

Of the twelve cases won by the Tribes, nine reinforced the sovereign rights of Indian tribes, while three negatively impacted state power by denying state taxing authority inside Indian Country. ${ }^{38}$ Of the nine cases that reinforced tribal sovereign rights were the following: two upheld tribal sovereign immunity from suits, ${ }^{39}$ one and a half upheld tribal

35 For the purposes of this section, the Article does not include Lincoln v. Vigil, 508 U.S. 192 (2011) or Oklahoma Tax Comm'n v. Graham, 489 U.S. 838 (1989). Both cases did not easily fit in any of the four categories named above. See discussion, supra notes 142-143.

${ }^{36}$ California v. Cabazon Band of Mission Indians, 480 U.S. 202 (1987), is being counted here as half a political rights case and half an economic rights case since it denied the states the jurisdiction to regulate gaming in Indian Country.

37 Brendale v. Confederated Tribes, 492 U.S. 408 (1990).

38 Okla. Tax Comm'n v. Citizen Band of Potawatomi, 498 U.S. 505 (1991); Okla. Tax Comm'n v. Sac \& Fox Nation, 508 U.S. 114 (1993); Okla. Tax Comm'n, v. Chickasaw Nation, 515 U.S. 450 (1995). For the definition of Indian Country see supra note 47.

39 Michigan v. Bay Mills Indian Cmty., 124 U.S. 2024 (2014); Kiowa Tribe v. Mfg. Techs., 523 U.S. 751 (1998). 
civil jurisdiction over non-members, ${ }^{40}$ one upheld tribal jurisdiction under the Indian Child Welfare Act, ${ }^{41}$ and one mandated exhaustion of tribal court remedies before a law suit challenging tribal jurisdiction could be filed in federal court. ${ }^{42}$ Two of the more important wins were California $v$. Cabazon Band of Mission Indians, where the Court rejected state jurisdiction over Indian gaming, ${ }^{43}$ and United States $v$. Lara, where the Court held that Supreme Court decisions divesting Indian tribes of jurisdiction over non-members were decisions based on federal common law and as such could be overturned by Congress. ${ }^{44}$ More recently, one case allowed tribal convictions to be counted for the purpose of federal sentencing; ${ }^{45}$ another case held that an Indian reservation had not been disestablished. ${ }^{46}$

The twenty-six and a half losses can be divided between cases extending or recognizing state power over Indian Country ${ }^{47}$ or Indian Affairs and cases that reduced tribal power.

Thirteen and a half cases negatively impact tribal sovereignty: seven and a half cases denied tribal civil or criminal jurisdiction over non-members, ${ }^{48}$ five cases either

${ }^{40}$ Dollar Gen. v. Miss. Choctaw, 136 S. Ct. 2159 (2016); and half of Brendale v. Confederated Tribes, 492 U.S. 408 (1990).

${ }^{41}$ Miss. Band of Choctaw v. Holyfield, 490 U.S. 30 (1989).

${ }^{42}$ Iowa Mutual Insurance Co. v. LaPlante, 480 U.S. 9 (1987).

${ }^{43}$ California v. Cabazon Band of Mission Indians, 480 U.S. 202 (1987).

${ }^{44}$ United States v. Lara, 541 U.S. 193 (2004).

${ }^{45}$ United States v. Bryant, 136 S. Ct. 1954 (2016).

${ }^{46}$ Nebraska v. Parker, 136 S. Ct. 1072 (2016).

47 "Indian Country" is a term of art defined in 18 U.S.C. 1151. It includes all lands within Indian reservations as well as land held in trust or restricted fee by the United States for the benefit of Indians, and land set aside by the United States for Dependent Indian Communities.

${ }^{48}$ Duro v. Reina, 495 U.S. 676 (1990); South Dakota v. Bourland, 508 U.S. 679 (1993); Strate v. A-1 Contractors, 520 U.S. 438 (1997); Atkinson Trading v. Shirley, 532 U.S. 645 (2001); Nevada v. Hicks, 533 U.S. 353 (2001); Plains Commerce Bank v. Long Family Land \& Cattle Co., 554 U.S. 316 (2008); Brendale v. Confederated Tribes, 492 U.S. 408 (1980); El Paso Natural Gas v. Neztsosie, 526 U.S. 473 (1999). 
prevented ribes from suing states ${ }^{49}$ or refused to extend tribal sovereign immunity, ${ }^{50}$ and one case refused to limit election to the State Commission on Native Hawaiian Affairs to Native Hawaiians. 51

Thirteen cases can be described as allowing state jurisdiction. While eight of these cases dealt with the authority of states to tax, ${ }^{52}$ one extended state criminal jurisdiction in Kansas, ${ }^{53}$ and three others diminished the extent of Indian country, thereby extending state general authority over these areas. ${ }^{54}$ Finally, one case narrowed the application of the Indian Child Welfare Act (ICWA), implicitly extending state authority over such cases. ${ }^{55}$

\section{Economic/property rights: 14.5 cases.}

This section concerns tribal rights, more easily described as property rights or economic rights. Not included in this category are cases where the court was deciding the continued existence of Indian Country. ${ }^{56}$ While those cases,

49 Seminole Tribe v. Florida, 517 U.S. 44 (1996); Blatchford v. Native Vill. of Noatak, 501 U.S. 775 (1991); and Inyo Cty. v. Paiute Shoshone Indians, 538 U.S. 701 (2003).

50 Lewis v. Clarke, 137 S. Ct. 1285 (2017) (refusing to extend tribal sovereign immunity to tribal employees committing torts off the reservation but within the scope of their employment); C\&L Enter. v. Citizens Band of Potawatomi, 532 U.S. 422 (2001) (finding an explicit waiver of tribal sovereign immunity).

${ }^{51}$ Rice v. Cayetano, 528 U.S. 495 (1990).

52 Cotton Petroleum v. New Mexico, 490 U.S. 163 (1989); Dep't of Taxation v. Milhelm, 512 U.S. 679 (1994); Montana v. Crow Tribe, 523 U.S. 696 (1998); Ariz. Dep't of Revenue v. Blaze Constr., 526 U.S. 32 (1999); City of Sherrill v. Oneida Indian Nation, 544 U.S. 197 (2005); Wagnon v. Prairie Band Potawatomi Nation, 546 U.S. 95 (2005); Cty. of Yakima v. Confederated Tribes, 502 U.S. 251 (1992); and Cass Cty. v. Leech Lake Band, 524 U.S. 103 (1998).

${ }^{53}$ Negonsott v. Samuels, 507 U.S. 99 (1993).

54 Alaska v. Vill. of Venetie, 522 U.S. 520 (1998); South Dakota v. Yankton Sioux Tribe, 522 U.S. 329 (1988); and Hagen v. Utah, 510 U.S. 399 (1994).

55 Adoptive Couple v. Baby Girl, 133 S. Ct. 2552 (2013) (holding that a biological father who never had "custody" of his child is not eligible to take advantage of the Act to challenge an adoption proceeding).

56 Nebraska v. Parker, 136 S. Ct. 1072 (2016); Alaska v. Vill. of Venetie, 522 U.S. 520 (1998); South Dakota v. Yankton Sioux Tribe, 522 U.S. 329 (1988); and Hagen v. Utah, 510 U.S. 399 (1994). 
such as the ones involving the disestablishment of Indian reservations have certainly have some economic or property aspect to them, they are primarily about which body may assume jurisdiction over certain issues - the tribes, the states, or the federal government. Therefore, they are more correctly categorized as political rights cases.

Of these fourteen and a half cases, tribal interests won five and a half cases and lost nine, which amounts to a $37.9 \%$ tribal win rate. This is the highest tribal win rate of the four categories. The most meaningful tribal victory was California $v$. Cabazon Band of Mission Indians, ${ }^{57}$ which continued to interpret P.L. 280 as not allowing state civil regulatory jurisdiction in Indian Country. ${ }^{58}$ Besides Cabazon, the tribal wins include two tribal contract disputes under the Indian Self-Determination Act, ${ }^{59}$ two cases interpreting treaties or agreements with Indian Nations, ${ }^{60}$ and one Indian water rights case, Arizona v. California. ${ }^{61}$

The tribal losses are eclectic and, therefore, not easily categorized. They range from an early case dealing with the subsistence rights of Native Alaskans, ${ }^{62}$ to a case allowing federal taxation of Indian gaming. ${ }^{63}$ Another three cases dealt with tribal attempts to confirm property rights in minerals, ${ }^{64}$ or submerged land. ${ }^{65}$ Two other cases disallowed minimal individual interests in land to escheat to tribes, ${ }^{66}$ while another applied the statute of limitations to a contract dispute between a tribe and the United States. ${ }^{67}$ Finally,

57 California v. Cabazon Band of Mission Indians, 480 U.S. 202 (1987).

58 The case is included in this section as counting for half a case since it is also included for half a case in the sovereign/political rights section.

59 Salazar v. Ramah Navajo, 132 S. Ct. 2181 (2012); Cherokee Nation v. Leavitt, 543 U.S. 631 (2005).

60 Minnesota v. Mille Lacs Band of Chippewa, 526 U.S. 172 (1999); Idaho v. United States, 533 U.S. 262 (2001).

61 Arizona v. California, 530 U.S. 392 (2000).

62 Amoco Prod. v. Gambell, 480 U.S. 531 (1987).

${ }^{63}$ Chickasaw Nation v. United States, 534 U.S. 84 (2001).

${ }^{64}$ Amoco Prod. v. Southern Ute Tribe, 526 U.S. 865 (1999).

65 Idaho v. Coeur d'Alene 521 U.S. 261 (1997); United States v. Cherokee Nation, 480 U.S. 700 (1987).

${ }^{66}$ Hodel v. Irving, 481 U.S. 704 (1987); Babbitt v. Youpee, 519 U.S. 234 (1997).

${ }^{67}$ Menominee v. United States, 136 S. Ct. 750 (2016). 
another case allowed the state of Hawaii to continue the sale of lands that were originally ceded by the Kingdom of Hawaii. ${ }^{6}$

\section{Rights derived from the Federal-trust relationship: 8 cases.}

There were eight cases that, in some form or another, interpreted the trust relationship Indian nations have with the United States. Since 1831, when Chief Justice Marshall in Cherokee Nation v. Georgia refused to consider Indian nations as foreign nations and instead described them as domestic dependent nations whose relationship with the United States resembled that of a ward to its guardian, ${ }^{69}$ the political relationship between the United States and the tribes has been described as a trust relationship. ${ }^{70}$ Under that relationship, tribes are the beneficiary of the trust and the United States is the trustee. In these eight Indian trust doctrine cases, tribal interests won only one case, a breach of trust claim against the United States, ${ }^{71}$ and lost seven (a $12.5 \%$ winning rate). The tribal losses included three breachof-trust claims. ${ }^{72}$ In two other cases, tribes attempted, without success, to apply the Indian trust doctrine to statutes and doctrines of general applicability, meaning statutes or doctrines not specifically directed at Indians or Indian

\footnotetext{
68 Hawaii v. Office of Haw. Affairs, 556 U.S. 163 (2009).

${ }^{69}$ Cherokee Nation v. Georgia, 30 U.S. 1, 17 (1831) (holding that Indian tribes, being neither foreign nations nor states of the Union, could not invoke the original jurisdiction of the Supreme Court).

${ }^{70}$ For a comprehensive treatment of the trust doctrine, see Mary Christina Wood, Indian Land and the Promise of Native Sovereignty, The Trust Doctrine Revisited, 1994 UTAH L. REV. 1471 (1994).

71 United States v. White Mountain Apache Tribe, 537 U.S. 465 (2003).

72 United States v. Navajo Nation, 537 U.S. 488 (2003) ("Navajo I"), and United States v. Navajo Nation, 556 U.S. 287 (2009) ("Navajo II") (both cases finding that no statutes allowed the Navajo Nation to successfully sue the United states for breach of trust). United States $v$. Tohono O'Odham, 563 U.S. 307 (2011), is included here although the Tribe was not allowed to sue the United States for breach of trust in the Federal Court of Claims only because it had already filed a similar case in federal district court.
} 
tribes. ${ }^{73}$ Finally, in Patchak, the Court allowed non-Indian individuals to challenge the United States' decision to take land into trust for Indian tribes, ${ }^{74}$ while in Carcieri $v$. Salazar 75 it restricted the application of Section 5 of the Indian Reorganization Act to tribes under federal jurisdiction as of 1934.76

The low rate of tribal wins in this area indicates that the Court is construing trust obligations narrowly. ${ }^{77}$ The Court also does not want to extend general principles of trust law to interpret the extent of the Indian trust doctrine unless specifically mandated to do so by Congress. ${ }^{78}$

\section{Cultural/Religious Rights: 3 cases.}

There are only three cases in this category and, unfortunately, tribal interests lost every one of them. Two of the cases, Matal v. Tam ${ }^{79}$ and Employment Division $v$. Smith, ${ }^{80}$ were not concerned per se with any doctrines of federal Indian law. Matal is a non-Indian law case holding that the use of arguably racially offensive words in trademarks is protected by the free speech clause of the First Amendment. The holding in Matal, however, doomed the efforts of Indians to force the National Football League to abandon the "Redskins" trademark. ${ }^{81}$ Employment Division $v$. Smith dealt with whether the use of peyote as a sacrament

${ }^{73}$ United States v. Jicarilla Apache Nation, 564 U.S. 162 (2011) (refusing to apply the trust doctrine to allow the Tribe to benefit from the "fiduciary exception" to the attorney-client privilege); Dep't of Interior v. Klamath River Water Users, 532 U.S. 1 (2001) (refusing to apply the trust doctrine to exceptions contained in the Freedom of Information Act (FOIA).

74 Match-E-B-Nash-She-Wish Band v. Patchak, 567 U.S. 209 (2012).

75 Carcieri v. Salazar, 555 U.S. 379 (2009).

76 Section 5, codified at 25 U.S.C. 5108, authorizes the Secretary of the Interior to take land into trust for the benefit of Indians.

77 See Navajo I, 537 U.S. at 509-13 (finding that neither the Indian Mineral Leasing Act or any other Acts of Congress imposed a trust duty that was specific enough to give rise to a cause of action for the breach of any duty connected to the Secretarial approval of the Navajo lease with Peabody Coal Corporation).

78 See U.S. v. Jicarilla Apache Nation, 564 U.S. 162 (2011).

${ }^{79}$ Matal v. Tam, 137 S. Ct. 1744 (2017).

80 Employment Division v. Smith, 494 U.S. 872 (1990).

81 See Pro-Football v. Blackhorse, 112 F. Supp. 3d 439 (2015). 
in Native American religious practices was protected under the free exercise clause of the First Amendment. The Court held that criminal laws of general applicability that only incidentally imposed burdens on the exercise of religion cannot be challenged under the free exercise clause of the First Amendment. The constitutional principle devised by the Court to decide the case affected all religions. The third case, Lyng $v$. Northwest Indian Cemetery, ${ }^{82}$ held that nearly all federal actions negatively impacting Native American sacred sites located on federal land could not be challenged under the free exercise clause because such actions did not substantially burden the religious practices of Native American practitioners. ${ }^{83}$

\section{B. The Record Based on the Type of Law Used to Decide the Cases.}

This part divides the cases into four categories: federal common law, statutory/treaty interpretation, constitutional law, and procedural law. ${ }^{84}$ (The relevant federal Indian law cases all fit into one of these four categories. In spite of strong arguments from various scholars that evolving norms of international law, ${ }^{85}$ such as the 2007 United Nations Declaration on the Rights of Indigenous Peoples, 86 should provide the rules of decisions in many Indian law cases, the Court has, unfortunately, not heeded that recommendation. ${ }^{87}$ ) With regard to categorization, whether a case is decided using federal common law or constitutional law is usually readily

82 Lyng v. Northwest Cemetery Ass., 485 U.S. 439 (1988).

${ }^{83}$ Id. For an in-depth analysis of the case, see Alex Tallchief Skibine, Towards a Balanced Approached for the Protection of Native American Sacred Sites, 17 MicH. J. OF RACE \& L. 269, 279-88 (2012).

84 This last category is, in effect, a residual one containing all cases not fitting in the first three categories.

85 See Robert A. Williams Jr., Like a LoAded Weapon: The Rehnquist Court, Indian Rights, AND THE LeGAL History of RACISM IN AMERICA (2005); Philip P. Frickey, Domesticating Federal Indian Law, 81 Minn. L. REV. 31 (1996).

${ }^{86}$ Declaration on the Rights of Indigenous Peoples, G.A. Res. 61/295, 12, U.N. Doc. A/RES/61/295 (Sept. 12, 2007).

${ }^{87}$ See Kristen A. Carpenter \& Angela R. Riley, Indigenous Peoples and the Jurisgenerative Moment in Human Rights, 102 CALIF. L. REV. 173 (2014). 
identifiable, although that issue was the subject of at least one Supreme Court decision in federal Indian law. ${ }^{88}$

1. Federal Common law decisions: 28.5 cases.

Historically, the Court has left the role of governing the United States relations with the Indian nations to Congress, so one would think that most of the cases would be about interpreting statutes defining the relationships between the tribes, the states, and the federal government. Perhaps surprisingly, the Court uses federal common law more than any other type of law when deciding cases involving tribal interests. The survey indicates that twenty-eight and a half cases, out of a total of sixty-six cases, were decided on federal common law grounds. ${ }^{89}$ Of these federal common law cases, tribal interests won nine and lost nineteen and a half cases (a tribal win/loss ratio of $31.5 \%$ ).

Of the wins, one case was the 4-4 decision without an opinion in Dollar General, ${ }^{90}$ two upheld tribal sovereign immunity, ${ }^{91}$ one allowed a tribe to sue the United States for breach of trust in the management of trust assets, ${ }^{92}$ and one was half of Brendale $v$. Confederated Tribes which allowed tribal jurisdiction over non-members in the "closed" parts of the reservation. ${ }^{93}$ Two of the more meaningful wins came early on. In California v. Cabazon Band of Mission Indians, the tribe was allowed to conduct certain gaming activities free of state regulation, ${ }^{94}$ and in Iowa Mutual Insurance Co. $v$. LaPlante, 95 the Court reaffirmed and extended the

88 United States v. Lara, 541 U.S. 193 (2004) (holding that cases divesting Indian tribes of inherent sovereignty are based on federal common law and not constitutional law).

89 The one half is the result of considering California v. Cabazon Band, 480 U.S. 202 (1987), as half a statutory interpretation case and half a federal common law case.

90 See discussion, supra notes 33-34.

${ }^{91}$ Michigan v. Bay Mills Indian Cmty., 124 U.S. 2024 (2014); Kiowa Tribe v. Mfg. Techs., 523 U.S. 751 (1998).

92 United States v. White Mountain Apache Tribe, 537 U.S. 465 (2003).

93 Brendale v. Confederated Tribes, 492 U.S. 408 (1990).

94 California v. Cabazon Band of Mission Indians, 480 U.S. 202 (1987).

95 Iowa Mut. Ins. Co. v. LaPlante, 480 U.S. 9 (1987). 
requirement that non-members being sued in tribal court should first have to exhaust their tribal court remedies before challenging tribal jurisdiction in federal court. In addition, the tribal percentage of wins reflects three of tribal wins against the Oklahoma Tax Commission, the outcomes of which may have been the result of an overly aggressive antitribal agenda on behalf of that Commission. ${ }^{96}$

The tribal loss category can be divided into four subcategories: 1. Tribal jurisdiction over non-members; 2. State taxation inside Indian reservations; 3. Cases interpreting the trust doctrine; and 4. Cases involving tribal or state sovereign immunity.

Tribal interests lost six and a half cases out of seven and a half cases involving tribal jurisdiction over nonmembers. ${ }^{97}$ Tribal interests also lost six cases involving the states' attempts to tax activities on Indian land or Indian reservations. ${ }^{98}$ Judicial interpretation of the trust doctrine also proved detrimental to tribes as tribal interests lost four cases. Two cases involved the Navajo Nation's attempts to sue

96 See Okla. Tax Comm'n v. Citizen Band of Potawatomi, 498 U.S. 505 (1991); Okla. Tax Comm'n v. Sac \& Fox Nation, 508 U.S. 114 (1993); Okla. Tax Comm'n, v. Chickasaw Nation, 515 U.S. 450 (1995). It is noteworthy that these are the only three cases Indian nations won fighting the states' attempts to tax activities in Indian Country using the Indian preemption doctrine after 1989, the year the Court issued its decision in Cotton Petroleum v. New Mexico, 490 U.S. 163 (1989). The author has argued elsewhere that this 1989 opinion profoundly modified the nature of the Indian preemption doctrine. See Alex Tallchief Skibine, Formalism and Judicial Supremacy in Federal Indian Law, 32 AM. IND. L. REV. 391, 42021 (2007-2008).

97 The six cases are: Duro v. Reina, 495 U.S. 676 (1990); South Dakota v. Bourland, 508 U.S. 679 (1993); Strate v. A-1 Contractors, 520 U.S. 438 (1997); Atkinson Trading v. Shirley, 532 U.S. 645 (2001); Nevada v. Hicks, 533 U.S. 353 (2001); and Plains Commerce Bank v. Long Family Land \& Cattle Co., 554 U.S. 316 (2008). The tribes also lost half of Brendale v. Confederated Tribes, 492 U.S. 408 (1990).

98 Cotton Petroleum v. New Mexico, 490 U.S. 163 (1989); Dep't of Taxation v. Milhelm, 512 U.S. 679 (1994); Montana v. Crow Tribe, 523 U.S. 696 (1998); Ariz. Dep't of Revenue v. Blaze Constr., 526 U.S. 32 (1999); City of Sherrill v. Oneida Indian Nation, 544 U.S. 197 (2005); and Wagnon v. Prairie Band Potawatomi Nation, 546 U.S. 95 (2005). 
the United States for breach of trust. ${ }^{99}$ Another one involved a tribal attempt to apply the trust doctrine to the Freedom of Information Act. 100 Perhaps the most important case, in a jurisprudential sense, is United States v. Jicarilla Apache Nation, ${ }^{101}$ which held that the Indian tribe could not benefit from the "fiduciary exception" to the attorney-client privilege when attempting to get documents from its trustee, the United States. The importance of this case stems from language in the opinion indicating that, absent specific statutory language, the general law of trust could not be imported to further define the duties of the United States as trustee for the Tribes because its role as trustee was so different than that of a regular trustee. ${ }^{102}$ Tribal interests also lost three cases dealing with sovereign immunity. Two cases involved tribal sovereign Immunity, ${ }^{103}$ and one the sovereign immunity of the states. ${ }^{104}$

In conclusion, among the cases decided on federal common law grounds, tribes won in the area of tribal

99 United States v. Navajo Nation, 537 U.S. 488 (2003) ("Navajo I") and United States v. Navajo Nation, 556 U.S. 287 (2009) ("Navajo II") (both cases finding that no statutes allowed the Navajo Nation the right to sue the United states for breach of trust). While both cases could be classified as involving statutory construction in that the issue was whether statutes could fairly be interpreted as allowing a breach of trust action against the United States for mismanagement of trust assets, I view them as being more about applying the Indian trust doctrine to the interpretation of statutes than just cases about statutory interpretation.

100 Dep't of Interior v. Klamath River Water Users, 532 U.S. 1 (2000) (Trust doctrine does not create a tribal exception to FOIA).

101 U.S. v. Jicarilla Apache Nation, 564 U.S. 162 (2011).

${ }^{102} I d$. at $174-77$.

103 C.L. Enter. v. Citizens Band of Potawatomi Indian Tribe, 532 U.S. 422 (2001) (holding that the Tribe had waived its immunity) and Lewis v. Clark, 137 S. Ct. 1285 (2017) (refusing to extend the sovereign immunity of the Tribe to tribal employees committing torts off the reservation while on tribal assignment).

${ }^{104}$ Idaho v. Coeur d'Alene, 521 U.S. 261, 287 (1997) (refusing to extend the Ex parte Young doctrine to allow the tribe to sue the State, stating "It is apparent, then, that if the Tribe were to prevail, Idaho's sovereign interest in its lands and waters would be affected in a degree fully as intrusive as almost any conceivable retroactive levy upon funds in its Treasury. Under these particular and special circumstances, we find the Young exception inapplicable."). 
sovereign immunity and preventing assertion of tax jurisdiction by Oklahoma in the three cases involving the Oklahoma Tax Commission. Otherwise, tribal interests lost all six cases involving assertion of tribal jurisdiction over nonmembers. The tribes also lost six cases involving state taxation of activities in Indian Country. Clearly, the Court used federal common law mostly to protect non-members from tribal jurisdiction and to promote state sovereignty (through taxation) inside Indian Country.

\section{Statutory Interpretation cases: 21.5 cases.}

Among the sixty-six cases, twenty-one and a half involved statutory/treaty interpretation. Among those, the tribal interests lost fifteen and won six and a half cases or $30.2 \%$ of all the cases in this category. It is interesting to note that beside Cabazon (counting for half a case), ${ }^{105}$ all other six tribal wins involved interpretations of Indian specific legislation. Two involved interpretation of the Indian SelfDetermination Act. ${ }^{106}$ Two more involved treaty and quasi treaty interpretations. ${ }^{107}$ The oldest case decided in this category involved interpretation of the Indian Child Welfare Act, 108 and the last decided case, Nebraska v. Parker, involved federal legislation which was alleged to have disestablished an Indian reservation. ${ }^{109}$

105 California v. Cabazon Band of Mission Indians, 480 U.S. 202 (1987) (interpreting P.L. 280 as not allowing state civil regulatory jurisdiction over Indian gaming).

106 Salazar v. Ramah Navajo Chapter, 132 S. Ct. 2181 (2012); Cherokee Nation v. Leavitt, 543 U.S. 631 (2005). Interestingly, in the seven years separating these two cases, tribal interests did not win one case at the Supreme Court.

${ }_{107}$ Minnesota v. Mille Lacs Band of Chippewa, 526 U.S. 172 (1999) and Idaho v. United States, 533 U.S. 262 (2001). This is labeled a quasi-treaty case because the Court had to interpret an 1891 Act that ratified two previous tribal agreements made with the Coeur D'Alene Tribe. The Court held that Congress intended to reserve all submerged land under lakes and rivers when it legislatively ratified these two previous tribal agreements. 108 Miss. Band of Choctaw Indians v. Holyfield, 490 U.S. 30 (1989).

109 Nebraska v. Parker, 136 S. Ct. 1072 (2016). 
Among the tribal losses, ten cases involved Indian specific legislation, and five involved general type of legislation. The Indian specific legislation included an interpretation of the Indian Child Welfare Act, ${ }^{110}$ a tax provision of the Indian Gaming Regulatory Act, 111 an interpretation of the Indian Reorganization Act, ${ }^{112}$ and an interpretation of the Alaska Native Claims Settlement Act (ANCSA). ${ }^{113}$ In addition, two cases interpreted the General Allotment Act and the Burke Act, to allow state taxation of Indian-owned fee patented lands. 114 Two other cases interpreted Acts opening up Indian reservations for nonIndian settlers as terminating reservation status. ${ }^{115}$ Another case interpreted a Kansas act as conferring criminal jurisdiction on the State. ${ }^{116}$ Finally, in Hawaii v. Office of Hawaiian Affairs, 117 the Court held that when Congress enacted the Native Hawaiian Apology Resolution, it did not intend to strip the state of Hawaii of its sovereign power to alienate lands, which had previously been ceded by the

110 Adoptive Couple v. Baby Girl, 133 S. Ct. 2552 (2013).

111 Chickasaw Nation v. United States, 534 U.S. 84 (2001).

112 Carcieri v. Salazar, 555 U.S. 379, 382 (2009) ("for purposes of $§ 479$, the phrase "now under Federal jurisdiction" refers to a tribe that was under federal jurisdiction at the time of the statute's enactment. As a result, $\S 479$ limits the Secretary's authority to taking land into trust for the purpose of providing land to members of a tribe that was under federal jurisdiction when the IRA was enacted in June 1934.").

113 Alaska v. Native Vill. of Venetie, 522 U.S. 520 (1998) (holding that sections of the law reserving lands for Indians in fee simple did not create "Indian Country" as that term is defined in 18 U.S.C. 1151).

${ }^{114}$ Cty. of Yakima v. Confederated Tribes, 502 U.S. 251 (1992); Cass Cty. v. Leech Lake Band, 524 U.S. 103 (1998) (holding that when Congress makes Indian or tribal land freely alienable, it clearly signifies an intent to allow state taxation of such lands).

115 South Dakota v. Yankton Sioux Tribe, 522 U.S. 329 (1998) and Hagen v. Utah, 510 U.S. 399 (1994).

116 Negonsott v. Samuels, 507 U.S. 99 (1993).

${ }^{117}$ Hawaii v. Office of Haw. Affairs, 556 U.S. 163, 172 (2009) ("turning to the merits, we must decide whether the Apology Resolution 'strips Hawaii of its sovereign authority to sell, exchange, or transfer,' the lands that the United States held in 'absolute fee,' and 'grant[ed] to the State of Hawaii, effective upon its admission into the Union,' We conclude that the Apology Resolution has no such effect."). 
Kingdom of Hawaii to the United States and then transferred to the State.

Among the five losses involving general and not Indian specific legislation, one case dealt with interpretation of the Administrative Procedure Act and the Quiet Title Act. ${ }^{118}$ Another case one held that Indian tribes were not "persons" for the purposes of being allowed to sue under Section 1983. ${ }^{119}$ One case held that because claims brought under the PriceAnderson Act required federal court jurisdiction, exhaustion of tribal court remedies could not be mandated. ${ }^{120}$ Another one held that the Coal Lands Acts of 1909 and 1910 conveyed everything to the non-Indian surface patentees except the coal, which had been reserved to the United States. ${ }^{121}$ Therefore, it was these patentees and not the Tribe who owned the coal bed methane gas under the land. Finally one case dealt with the rights of Alaska Natives under the Alaska National Interest Lands Conservation Act (ANILCA). ${ }^{122}$

In conclusion, tribal interests were less successful in litigating statutory cases than cases based on federal common law. However, tribes won more than half the cases interpreting Indian specific statutes.

\section{Constitutional Law: 11 cases.}

Cases decided on constitutional grounds were even more detrimental to tribal interests than the two previously discussed areas - a total of eleven cases. The tribes only won two cases and lost nine (an $18.1 \%$ rate of success).

118 Mach-E-B-Nash-She-Wish Band v. Patchak, 567 U.S. 209 (2012).

119 Inyo Cty. v. Paiute Shoshone Indians, 538 U.S. 701 (2003). 42 U.S.C. Section 1983 provides that any person deprived of rights guaranteed under the Constitution or by federal law can sue any person responsible for such deprivation as long as that person was acting under color of state law.

120 El Paso Natural Gas v. Neztsosie, 526 U.S. 473 (1999). The PriceAnderson Act regulates liability for nuclear incident. In this case, Navajos brought actions relating to injuries suffered as a result of extraction of uranium. The Court held that of the Price-Anderson Act's preemption provision, 42 U.S.C. 2014(hh), provided for exclusive federal court jurisdiction.

121 Amoco Prod. v. Southern Ute Tribe, 526 U.S. 865 (1999).

${ }^{122}$ Amoco Prod. v. Gambell, 480 U.S. 531 (1987). 
The major tribal win, and some may say, the most significant win during this period, is United States v. Lara. ${ }^{123}$ There the Court held that decisions like Duro $v$. Reina (implicitly divesting tribes of criminal jurisdiction over nonmembers), were decisions based on federal common law and not constitutional law. As such, these decisions could be reversed or modified by Congress. ${ }^{124}$

The other tribal win was United States $v$. Bryant, ${ }^{125}$ holding that convictions obtained in tribal courts could be counted for the purpose of enhancing sentences in federal courts even if the defendants in tribal courts did not benefit from the assistance of counsel. Although the case is a win for recognizing the legitimacy of tribal courts within the federal system, some may argue that it is a loss for those who think that assistance of counsel is crucial to ensure a fair conviction for Indians being prosecuted in tribal court. ${ }^{126}$

Of the nine losses, three cases concerned First Amendment rights. Matal $v$. Tam held that the use of arguably racially offensive words in trademarks is protected by the free speech clause of the First Amendment. ${ }^{127}$ Employment Division v. Smith involved the use of peyote as a sacrament in Native American religious practices, and the Court held that criminal laws of general applicability that only incidentally impose burdens on the exercise of religion cannot be challenged under the free exercise clause of the First Amendment. ${ }^{128}$ Lyng v. Northwest Cemetery held that Native Americans could not use the free exercise clause to challenge federal actions negatively impacting Native

123 United States v. Lara, 541 U.S. 193 (2004).

124 For a general discussion of the case, see Alex T. Skibine, United States $v$. Lara, Indian Tribes, and the Dialectic of Incorporation, 40 TULSA L. REV. 47 (2004).

125 United States v. Bryant, 136 S. Ct. 1954 (2016).

${ }^{126}$ For a discussion of the issue, see Barbara L. Creel, The Right to Counsel for Indians Accused of a Crime: A Tribal and Congressional Imperative, 18 Mich. J. RACE \& L. 317, 358 (2013).

127 Matal v. Tam, 137 S. Ct. 1744 (2017). Although not per se an Indian case, the holding affected the efforts of Native Americans to make the Washington Redskins football team change its name. See Pro-Football v. Blackhorse, 112 F. Supp. 3d 439 (2015).

128 Employment Division v. Smith, 494 U.S. 872, 885 (1990). 
American sacred sites because such actions did not substantially burden the Native Americans' religious practices. ${ }^{129}$

Two cases involved property rights under the Fifth Amendment. Hodel v. Irving ${ }^{130}$ and Babbitt v. Youpee ${ }^{131}$ struck as unconstitutional the escheat provisions of the Indian Land Consolidation Act (ILCA). ${ }^{132}$ In both cases, the Court held that the escheat provisions amounted to the taking of property without just compensation. ${ }^{133}$ It is debatable whether Irving and Youpee are, strictly speaking, losses for tribal interests as the Court held that Congress could not, without adequate compensation, make individual Indians' minimal interest in land escheat to the tribes. ${ }^{134}$

Two cases, Blatchford v. Native Village of Noatak ${ }^{135}$ and Seminole Tribe $v$. Florida, ${ }^{136}$ prevented Indian nations from suing states in federal courts because of the states' sovereign immunity under the Eleventh Amendment. ${ }^{137}$ While undoubtedly very important to Indian interests, Seminole Tribe involved much more of a federal versus state conflict than a tribal versus state one as it held that Congress could not use its Commerce Clause power to abrogate the states' Eleventh Amendment immunity.

Finally, United States v. Cherokee Nation 138 involved the extent of the United States' navigational servitude under the Commerce Clause, and Rice $v$. Cayetano dealt with the

\footnotetext{
${ }^{129}$ Lyng v. Northwest Cemetery Ass., 485 U.S. 439 (1988).

${ }^{130}$ Hodel v. Irving, 481 U.S. 704 (1987).

131 Babbitt v. Youpee, 519 U.S. 234 (1997).

132 The current version of ILCA was codified at 25 U.S.C. 2201 et. seq.

${ }^{133}$ Irving invalidated the escheat provision of Section 207 found at 96 Stat. 2519, Youpee invalidated the provision at 98 Stat. 3173. The Indian Land Consolidation Act was further amended as a result of those two cases. The section that replaced former Section 207 containing the escheat provisions found unconstitutional was codified at 25 U.S.C. 2206.

134 See Baca, supra note 21, classifying the two cases as wins for Indians.

135 Blatchford v. Native Village of Noatak, 501 U.S. 775, 788 (1991).

136 Seminole Tribe v. Florida, 517 U.S. 44, 72 (1996).

137 The Eleventh Amendment provides: "The Judicial power of the United States shall not be construed to extend to any suit in law or equity, commenced or prosecuted against one of the United States by Citizens of another State, or by Citizens or Subjects of any Foreign State.”

138 United States v. Cherokee Nation, 480 U.S. 700 (1987).
} 
special status of Native Hawaiians under federal law. ${ }^{139}$ It held that a law restricting voting in a state election to "Native Hawaiians" was a racial classification and therefore unconstitutional under the Fifteenth Amendment.

4. Administrative/Civil Procedure Law: 5 cases.

There are only five cases in this category. Although tribal interests only won one of these cases, representing only a $20 \%$ win rate, this is by far the least important category since the cases here, while very important to the particular parties involved, do not represent important precedents concerning the status of Indian Nations within the federal system.

The one win was in Arizona v. California. ${ }^{140}$ The case was also the most meaningful among the five cases in this category. The decision held that the claim of the tribes and the United States to more water from the Colorado River was not precluded by previous decrees, nor was it barred under res judicata principles.

Among the four losses, one case involved a tribe losing the right to sue in the Federal Court of Claims because the Tribe had already filed a substantially similar case in a federal district court. ${ }^{141}$ Another one held that the Administrative Procedure Act did not prevent the right of an executive agency to reprogram monies from one Indian program to another. ${ }^{142}$ In Oklahoma Tax Commission $v$. Graham ${ }^{143}$ the Court remanded a case (decided in the tribe's favor at the lower level) but only because the case had initially been improperly removed to federal court. Finally, in Menominee v. United States, ${ }^{144}$ the Court held that the statute of limitation contained in the Contract Dispute Act was

\footnotetext{
139 Rice v. Cayetano, 528 U.S. 495 (2000).

140 Arizona v. California, 530 U.S. 392 (2000).

141 United States v. Tohono O'Odham, 563 U.S. 307 (2011).

142 Lincoln v. Vigil, 508 U.S. 182 (1993).

143 Oklahoma Tax Comm'n v. Graham, 489 U.S. 838 (1989).

${ }^{144}$ Menominee v. United States, 136 S. Ct. 750 (2016).
} 
applicable to a contract dispute between a tribe and the United States involving the Indian Self Determination Act.

\section{The Record When the Cases Are Considered along Time Lines.}

It is important to note that the overall percentage of tribal wins in the last thirty years, while not strong (28\%), has increased since Getches published his 2001 survey (23\%). ${ }^{145}$ However, if one looks at the percentages of tribal wins when the cases are divided into ten-year increments, the future looks brighter for tribal interests. From the 1987-1988 term to the 1996-1997 term, the Court adjudicated twenty-five cases. Of these, eighteen and a half were tribal losses, and six and a half were wins, ${ }^{146}$ amounting to a $26 \%$ tribal win rate. From the 1997-1998 term to the 2006-2007 term, the Court also heard twenty-five cases. The tribal interests lost eighteen cases, while winning seven. ${ }^{147}$ This amounts to a $28 \%$ Tribal

145 See Getches, Beyond Indian Law, supra note 18.

146 The two most important wins for the tribes during that decade were California v. Cabazon Band, 480 U.S. 202 (1987) (no state jurisdiction over Tribal gaming) and Mississippi Choctaw v. Holyfield, 490 U.S. 30 (1989) (ICWA). Meaningful losses include Cotton Petroleum v. New Mexico, 490 U.S. 163 (1989) (State taxation); Strate v. A-1 Contractors, 520 U.S. 438 (1997) (no tribal civil jurisdiction over non-members); Duro v. Reina, 495 U.S. 676 (1990) (no tribal criminal jurisdiction over non-member Indians); Seminole Tribe v. Florida, 517 U.S. 44 (1996) (state retained sovereign immunity in spite of IGRA); and Lyng v. Nw. Indian Cemetery, 485 U.S. 439 (1988) (no constitutional protection for Indian sacred site located on federal land).

${ }^{147}$ Among the more meaningful tribal wins in this decade are Kiowa Tribe v. Manufacturing Technologies, 523 U.S. 751 (1998) (tribal sovereign immunity); Minnesota v. Mille Lacs Band, 526 U.S. 172 (1999) (treaty rights); and United States v. Lara, 541 U.S. 193 (2004) (congressional power to overturn implicit divestiture cases). Important losses include Nevada v. Hicks, 533 U.S. 353 (2001) (no tribal civil jurisdiction over non-members); Alaska v. Village of Venetie, 522 U.S. 520 (1998) (land owned in Fee by Indians pursuant to ANCSA not Indian Country); United States v. Navajo Nation, 537 U.S. 488 (2003) (no U.S. liability for breach of trust in management of tribal natural resources); Atkinson Trading v. Shirley, 532 U.S. 645 (2001) (no tribal civil jurisdiction over non-members); and Rice v. Cayetano, 528 U.S. 495 (2000) (classification of Native Hawaiians for the purpose of voting in state elections are racial classifications reviewed under strict scrutiny). 
win rate. From the 2007-2008 until the 2016-2017 term, there was only sixteen cases. Eleven cases were tribal losses, and five tribal wins. ${ }^{148}$ This represents a $31.2 \%$ tribal win rate.

Although the tribal win rate increased in each successive decade, the pro-tribal trend is even more striking when one compares the first fifteen years (1987-1988 term until the 2000-2001 term) with the last fifteen years (2001-2002 term until the 2016-2017 term.) The tabulation shows that there were forty-three cases decided in the first fifteen years with the tribal interests losing thirty-two and a half cases while only winning ten and a half cases, representing a $24.4 \%$ rate of tribal wins. However, in the last fifteen years, there were only twenty-three cases. However, of these twenty-three cases, tribal interests won eight cases while losing fifteen. This represents a $34.7 \%$ rate of tribal wins and may indicate that, for the tribes, the worst is behind them and there might indeed be a light at the end of this anti tribal sovereignty tunnel. Besides the Court being receptive to the idea of including Indian tribes as the Third Sovereign within our federalist system, other factors may have contributed to this rather abrupt drop in the number of cases decided as well as the increase in the percentage of tribal wins. One of these factors could be the creation of the Tribal Supreme Court Project, a joint effort by the Native American Rights Fund and the National Congress of American Indians, to more closely monitor and control the kind of cases appealed to the Supreme Court by tribal interests. ${ }^{149}$

$$
* * *
$$

148 Meaningful tribal wins in this decade include Michigan v. Bay Mills, 134 S. Ct. 2024 (2014) (Tribal sovereign Immunity) and Nebraska v. Parker, 136 S. Ct. 1072 (2016) which is included as an important case because it may represent a turning point on how the Court determines whether Indian reservations have been disestablished. Important tribal losses include Pains Commerce Bank v. Long Family Land \& Cattle, 554 U.S. 316 (2008) (no tribal civil jurisdiction over non-members); U.S. v. Jicarilla Apache Tribe, 564 U.S. 162 (2011) (trust doctrine not applicable to interpret FOIA); Adoptive Couple v. Baby Girl, 133 S. Ct. 2552 (2013) (applicability of ICWA); and Carcieri v. Salazar, 555 U.S. 379 (2009) (Section 5 of IRA only applicable to tribes under federal jurisdiction as of 1934).

149 See Berger, Hope for Indian Tribes, supra note 20, at 1909-11. 
In conclusion, the Court invokes federal common law more frequently than any other type of law in deciding federal Indian law cases. In addition, cases involving tribal political rights are more numerous than cases in any other category and federal common law is used most often in deciding such political rights cases.

Although the Tribes won $31.2 \%$ of cases concerning political rights based on Federal common law, the odds of the tribes winning political rights cases based on statutory interpretation in this area was even less: two out of nine $(22 \%)$. In a somewhat curious twist, the tribes won two out of five (40\%) of the cases based on constitutional law affecting tribal political rights. ${ }^{150}$

However, the tribes' chance of winning cases based on federal common law, which stands at $28 \%$, is not as good as winning cases based on statutory construction, which have a $31.7 \%$ winning rate. Within the statutory construction category, tribal interests have the best chance of winning cases dealing with interpretation of Indian specific legislation as tribes won six of the sixteen cases in this area (37.5\% of the cases). Finally, the tribal win-loss ratio has improved in every decade since the 1986-1987 Supreme Court term.

\section{LOOKING FOR EQUILIBRIUM OR JUDICIAL SUPREMACY?}

\section{A. Evaluating Congressional Response to The Court's Decisions.}

Congress is said to have "plenary power" over Indian affairs, ${ }^{151}$ and through the Constitution, mostly through the

\footnotetext{
150 The tribes won in United States v. Lara and United States v. Bryant while losing in Seminole Tribe v. Florida, 517 U.S. 44 (1996); Rice v. Cayetano, 528 U.S. 495 (1990); and Blatchford v. Native Village of Noatak, 501 U.S. 775 (1991). The winning percentage here is curious because for all categories, the tribes lost nine of the eleven cases involving constitutional law. See discussion, supra notes 123-139.

151 For instance, in Cotton Petroleum v. New Mexico, 490 U.S. 163, 192 (1989), the Court stated, "the central function of the Indian Commerce Clause is to provide Congress with plenary power to legislate in the field of Indian affairs."
} 
Indian Commerce Clause, it is vested with primacy over Indian affairs. ${ }^{152}$ Recently, one scholar has argued that it is normatively right for Congress to take the leading role in Indian affairs because it has the better institutional capacity to formulate sound policies governing federal relations with Indian Nations, ${ }^{153}$ while another scholar demonstrated that Congress is still very active in formulating federal Indian policy. ${ }^{154}$ Others have argued, however, that Congress has ceded its leading role to the Court. ${ }^{155}$ Consistent with the views expressed in Law as Equilibrium, ${ }^{156}$ it is true that Congress and the Court, and at times the executive branch, are involved in a kind of ongoing dialogue with each other. As once stated by Justice Ginsburg: "Judges . . . participate in a dialogue with other organs of government." 157 This section analyzes the interplay between the Court and Congress in the field of federal Indian law to understand the nature of the dialogue and determine if the Court has taken control over such dialogue. ${ }^{158}$

Fletcher has persuasively shown that, generally speaking, "modern congressional statements" in federal Indian policy support tribal self-government, tribal tax authority and economic development, as well as tribal

152 The Commerce Clause, Article I, Section 8, Clause 3, of the U.S. Constitution provides that "Congress shall have the power . . . to regulate Commerce . . . with the Indian Tribes." For a thorough look at the various sources of congressional power over Indian Affairs, see Gregory Ablavsky, Beyond the Indian Commerce Clause, 124 YALE L.J. 1012 (2015).

153 See Michalyn Steele, Comparative Institutional Competency and Sovereignty in Indian Affairs, 85 U. COLO. L. REV 759 (2014).

${ }^{154}$ Carlson, Congress and Indians, supra note 28, at 148-49.

155 See Fletcher, Federal Indian Policy, supra note 15.

156 See Eskridge \& Frickey, Law as Equilibrium, supra note 22.

${ }^{157}$ Ruth Bader Ginsburg, Speaking in a Judicial Voice, 67 N.Y.U. L. REV. 1185, 1198 (1992). See also Lawrence Friedman, The Constitutional Value of Dialogue and the New Judicial Federalism, 28 Hasting Const. L. Q. 93 (2000); Maimon Schwarzchild, Pluralism, Conversation, and Judicial Restraint, 95 Nw. U. L. REV. 961 (2001) (discussing when court decisions encourage democratic conversations with the other branches.)

158 For a comprehensive study of the dynamic relationship between the Court's decision and Congress on all issues, see William N. Eskridge Jr., Overriding Supreme Court Statutory Interpretation Decisions, 101 YALE L.J. 331 (1991). 
sovereign immunity and the development of tribal courts. ${ }^{159}$ This section focuses only on legislation enacted specifically as a response to a Supreme Court decision in order to evaluate congressional willingness/effort to retain primacy over Indian affairs and affirm its policy of tribal self-determination. Although many pieces of tribe-specific legislation, whether it be land claims or water rights settlements, are somewhat related to former Supreme Court decisions, this section does not analyze all congressional legislation that may have been only partially influenced by Supreme Court decisions. ${ }^{160}$

\section{Indian Gaming.}

Perhaps the most interesting case study involving the interaction between the three government branches in the field of Indian affairs is in the area of Indian gaming. Although Congress had been working on legislation to regulate Indian gaming for some time, it was only after the Court issued its 1987 decision in California v. Cabazon ${ }^{161}$ that Congress found the political will to enact the Indian Gaming Regulatory Act of 1988 (IGRA). ${ }^{162}$ Eight years after IGRA was enacted into law, the Court had the opportunity to respond to the legislation and declared the part of IGRA allowing Tribes to sue states for failing to negotiate tribal state compacts in

159 See Fletcher, Federal Indian Policy, supra note 15, at 140-50.

${ }^{160}$ Not included, for instance, are the twenty-seven tribal legislative water rights settlements enacted since 1978. For sure, Supreme Court cases, such as Winters v. United States, 207 U.S. 564 (1908), and Arizona v. California, 373 U.S. 546 (1963) that defined the extent of tribal water rights, and cases such as Arizona v. San Carlos Apache Tribe, 463 U.S. 545 (1983), allowing for state court adjudication of tribal water rights, played an important role in influencing the states and the tribes to settle their water rights dispute through legislation. However, these cases were all decided before 1986 and it would be inaccurate to say that these legislative settlements were a direct response to such cases. For an analysis of such water rights settlements, see Robert T. Anderson, Indian Water Rights, Practical Reasoning, and Negotiated Settlements, 80 CAL. L. REV. 1133 (2010).

161 California v. Cabazon Band of Mission Indians, 480 U.S. 202 (1987).

162 Pub. L. 199-497, 102 Stat. 2467 (1988) (codified at 25 U.S.C. 2701bet seq.). For comprehensive analysis, see Franklin Ducheneaux, The Indian Gaming Regulatory Act: Background and Legislative History, 42 ARIZ. ST. L. J. 99 (2010); Robert N. Clinton, Enactment of the Indian Gaming Regulatory Act of 1988: The Return of the Buffalo to Indian Country or Another Federal Usurpation of Tribal Sovereignty, 42 ARIZ. ST. L. J. 17 (2010). 
good faith to be unconstitutional. ${ }^{163}$ While that decision did not generate a reaction from Congress in the field of Indian gaming legislation, the executive branch responded by enacting new regulations allowing Tribes to bypass an assertion of state sovereign immunity by allowing them to ask the Secretary of the Interior to issue Class III gaming procedures. ${ }^{164}$ So far, the power of the Secretary to issue such procedures has been struck down by two circuit courts, ${ }^{165}$ but the Supreme Court has not yet decided to take a case challenging the validity of the regulations. ${ }^{166}$

\section{Tribal Criminal Jurisdiction over non- Indians and non-member Indians.}

Congress reacted to the Court's decisions to divest tribes of criminal jurisdiction over non-member Indians and non-Indians through legislation. In 1991, Congress enacted the so-called Duro Fix, 167 overturning the Court's 1990 decision in Duro $v$. Reina that held that tribal criminal jurisdiction over non-member Indians had been implicitly divested. ${ }^{168}$ Later on, Congress eventually enacted the 2013 VAWA Amendments. 169 These amendments partially overturned Oliphant $v$. Suquamish Indian Tribe, ${ }^{170}$ the decision that had found tribal criminal jurisdiction over nonIndians implicitly divested. The VAWA Amendments allowed

\footnotetext{
163 Seminole Tribe v. Florida, 517 U.S. 44 (1996) (holding that Congress could not use its Indian Commerce Clause power to abrogate the states' Eleventh Amendment sovereign immunity.)

164 The final regulations were issued in 1999. See 64 Fed. Reg. 17, 535-36, codified at 25 C.F.R. 291.

165 See Texas v. United States, 497 F.3d 491 (5th Cir. 2007), cert. denied, 129 C. Ct. 32 (2008) and New Mexico v. Dep't of the Interior, 854 F.3d 1207 (10th Cir. 2017).

166 For an argument supporting the Secretary's authority to issue such regulations, see Alex Tallchief Skibine, Indian Gaming and Cooperative Federalism, 42 ARIz. ST. L. J. 253, 293-96 (2010) (criticizing the Fifth Circuit opinion).

167 PUB. L. No. 102-137, 105 Stat 646 (codified as amended at 25 U.S.C. 1301).

168 Duro v. Reina, 495 U.S. 676 (1990).

169 Codified at 25 U.S.C. 1304.

170 Oliphant v. Suquamish Indian Tribe, 435 U.S. 191 (1978).
} 
Indian tribes to re-acquire criminal jurisdiction over some non-Indians committing acts of domestic violence against Indians residing in Indian Country. ${ }^{171}$

There was a legal challenge to Congress's power to overturn or modify cases such as Duro and Oliphant, but the Court held in United States v. Lara that "the statute seeks to adjust the tribes' status. It relaxes the restrictions, recognized in Duro, that the political branches had imposed on the tribes' exercise of inherent prosecutorial power." 172 Therefore, Congress could modify the results in such cases. ${ }^{173}$ Whether non-members can be prosecuted in tribal courts without the full protection of the United State constitution has not yet been decided. ${ }^{174}$

\section{Indian land Consolidation Act: ${ }^{175}$}

The Court twice struck as unconstitutional provisions of the Indian Land Consolidation Act (ILCA), ${ }^{176}$ allowing very small interests in land owned by tribal members to escheat to their tribe under certain conditions. Each time, Congress reacted by enacting a new version of the law. The first ILCA was enacted in 1983 and its escheat provision was declared unconstitutional in Hodel v. Irving. ${ }^{177}$ An amended version attempting to resolve the constitutional issues was enacted in

171 Tribes wishing to re-acquire such jurisdiction would have to meet a number of conditions. For background and implementation of the 2013 VAWA Amendments, see Angela R. Riley, Crime and Governance in Indian Country, 63 UCLA L. REV. 1564 (2016).

172 United States v. Lara, 541 U.S. 193, 200 (2004).

${ }^{173}$ For in depth analysis of the decision and its background, see Bethany R. Berger, United States $v$. Lara as a Story of Native Agency, 40 TULSA L. REV. 5 (2004) and Alex Tallchief Skibine, United States v. Lara, Indian Tribes, and the Dialectic of Incorporation, 40 TULSA L. REV. 48 (2004).

174 See Note, Tribal Criminal Jurisdiction after United States v. Lara: Answering the Constitutional Challenge to the Duro Fix, 93 CAL. L. REV. 847 (2005). See also Samuel E. Ennis, Reaffirming Indian Tribal Court Criminal Jurisdiction over Non-Indians: An Argument for a Statutory Abrogation of Oliphant, 57 UCLA L. REV. 553 (2009).

17525 U.S.C. $2201-2219$

176 Pub. L. 97-459, 96 Stat. 2517.

177 Hodel v. Irving, 481 U.S. 704 (1987). 
1984 but declared unconstitutional in Babbitt v. Youpee. ${ }^{178} \mathrm{~A}$ third version was enacted in 2000 , but was replaced by the 2004 American Indian Probate Reform Act before it could be implemented. ${ }^{179}$

\section{Overturning Patchak:}

Following the Court's decision in Mach-E-Be-NashShe-Wish v. Patchak, ${ }^{180}$ which had allowed a non-tribal member to challenge a decision by the Secretary of the Interior to transfer some land to the tribe from fee to trust, Congress enacted the 1994 Gun Lake Trust Land Reaffirmation Act. ${ }^{181}$ That Act attempted to overturn or, perhaps, moot the Court's decision in Patchak by reaffirming the Secretary's decision to take the land into trust and directing the dismissal of any action (future or pending) challenging such fee to trust transfer. The Court recently upheld the constitutionality of this legislation. ${ }^{182}$ The grant of cert may have seemed unusual as the case only concerned a tribe specific statute. However, the legal principles involved were important as they concerned the power of Congress to affect results reached in previous court decisions.

\section{Overturning Employment Division v. Smith. ${ }^{183}$}

Tribal interests were successful in overturning the practical effect of Employment Division when Congress amended the American Indian Religious Freedom Act in 1994. ${ }^{184}$ The 1994 Amendments protected the sacramental

\footnotetext{
178 Babbitt v. Youpee, 519 U.S. 234 (1997).

179 Pub. L. No. 106-462, 114 Stat. 1991.

180 Match-E-Be-Nash-She-Wish Band of Pottawatomi Indians v. Patchak, 567 U.S. 209 (2012).

181 Pub. L. No. 113-179, 128 Stat. 1913.

182 See Patchak v. Zinke, 138 S. Ct. 897 (2018).

183 Employment Division v. Smith, 494 U.S. 872 (1990) (holding that the strict scrutiny test of the Free Exercise Clause was not applicable when general criminal laws only incidentally impacted one's religious practices. Here, the use of Peyote for sacramental purposes.) See discussion, supra notes $80-81$.

18442 U.S.C. $1996(\mathrm{a})-(\mathrm{b})$
} 
use of peyote by practitioners of Indian religions by prohibiting any state or federal prosecution for such sacramental use. The Congress also responded more generally to Employment Division by enacting the Religious Freedom Restoration Act (RFRA) in 1994. ${ }^{185}$ RFRA restored the strict scrutiny/compelling interest test when a law of general applicability substantially burdened one's free exercise of religion. ${ }^{186}$ RFRA was not a product of tribal efforts but was lobbied for by a coalition of mainstream religious groups. ${ }^{187}$

\section{Responding to Lyng v. Northwest Indian Cemetery. ${ }^{188}$}

It is noteworthy that RFRA was not meant to directly affect the result in Lyng $v$. Northwest Cemetery. Lyng held that Indian religious practitioners could not invoke the free exercise clause to challenge federal actions negatively impacting religious sacred sites located on federal land because such federal actions had not "substantially burdened" their religious practices. ${ }^{189}$ The actual result in Lyng was, however, overturned when Congress designated some lands, which included the whole area at issue in Lyng, as permanent wilderness under the Smith River National Recreation Act. 190 Furthermore, in response to Lyng, Congress amended the National Historic Preservation Act (NHPA) in 1992 to add "properties of traditional and cultural importance to an Indian tribe" to properties eligible to be included in the National

18542 U.S.C. $2000 \mathrm{bb}-1-2000 \mathrm{bb}-4$.

186 AIRFA was declared unconstitutional but only as applied to states in City of Boerne v. Flores, 521 U.S. 507 (1997).

187 For background on this legislation, see Douglas Laycock \& Oliver S. Thomas, Interpreting the Religious Freedom Restoration Act, 73 TEX. L. REV. 209 (1994).

188 Lyng v. Northwest Cemetery Ass., 485 U.S. 439 (1988)

${ }^{189}$ Id. See Laycock \& Thomas, supra note 187, at 229. See also Navajo Nation v. United States Forest Serv., 535 F.3d 1058 (9th Cir. 2008) (en banc) (holding that the court was bound by the result in Lyng in spite of RFRA). For a comprehensive analysis of this Ninth Circuit decision, see Jonathan Knapp, Making Snow in the Desert: Defining Substantial Burden under RFRA, 36 ECOLOGY L. Q. 259 (2009).

190 See 16 U.S.C. 460 bbb-3(b)(2)(H) (2000). 
Register of Historic Places. ${ }^{191}$ In addition, Indian nations must now also be included in the consultation process provided in the NHPA. ${ }^{192}$

$$
* * *
$$

In a recent article analyzing in depth the actions of Congress concerning Indians, Kirsten Carlson found that Indian tribes were surprisingly adept at persuading Congress to enact legislation favorable to tribal interests. ${ }^{193}$ As the Patchak legislation shows, ${ }^{194}$ this is undoubtedly true when it comes to getting Congress to enact tribe specific bills or legislation not opposed by states or powerful non-tribal interests such as the interest groups that have prevented legislation preempting state taxation in Indian Country or amendments to the Indian Gaming Regulatory Act. ${ }^{195}$ Otherwise, the only major pan-tribal successes involving congressional reaction to Supreme Court decisions in the last thirty years have been the enactment of IGRA, the Duro Fix, the 1992 Amendments to the National Historic Preservation Act, the 2013 VAWA Amendments, and the 1994 Amendments to the American Indian Religious Freedom Act. There have been, of course, many other tribal legislative successes. But such successes, like for instance, the Tribal Law \& Order Act, ${ }^{196}$ or the Cobell Settlement, ${ }^{197}$ have not

19116 U.S.C. § 470a (d)(6)(a). See also Anderson, Berger, et al. AMERICAN INDIAN LAW, CASES AND COMMENTARY 802-03 (3d ed. 2008).

19216 U.S.C. $\S 470 a$ (d)(6)(b). See also Sarah Palmer, Cherie Shanteau, Barbara Osborne, Strategies for addressing Native Traditional Cultural Properties, 20 NAT. ResouRCES \& ENV'T 45 (2005).

${ }^{193}$ See Kirsten Matoy Carlson, Tribes Lobbying Congress: Who Wins and Why 9-12, Draft Report Presented at the Michigan State University's $13^{\text {th }}$ Annual Indigenous Law Conference (2017).

${ }^{194}$ See discussion, supra notes 180-182.

${ }^{195}$ See discussion, infra notes 223, 230.

196 Pub. L. 11-211, 124 Stat 2261.

${ }^{197}$ Pub. L. No. 11-291 (2010). The Cobell litigation involved a class action representing the claims of over 300,000 individuals having trust accounts with the United States. No doubt, the parties' willingness to legislatively settle that litigation was influenced by recent Supreme Court cases such as United States v. White Mountain Apache Tribe, 557 U.S. 465 (2003), and United States v. Navajo Nation, 537 U.S. 488 (2003), defining the circumstances under which the United States could be liable for breach of fiduciary duties. The legislative settlement of the Cobell litigation, however, 
been the result of a direct congressional reaction to a Supreme Court case. Others, like RFRA for instance, were not the product of tribal lobbying efforts. ${ }^{198}$

\section{B. Evaluating the Court's Reaction to Federal Legislation.}

This section evaluates the Court's reaction to congressional legislation to determine if the Court is looking for a political equilibrium in reaching results consistent with the positions of Congress on Indian issues.

\section{Interpreting the Indian Gaming Regulatory Act (IGRA).}

As stated earlier, the Court struck part of IGRA as unconstitutional in Seminole Tribe v. Florida. ${ }^{199}$ The Court also interpreted IGRA as allowing federal taxation of tribal gaming revenues in Chickasaw Nation $v$. United States. ${ }^{200}$ While Seminole Tribe obviously upset the carefully crafted balance reached by Congress between tribal and state interests in tribal gaming within Indian Country, the decision was part of a much larger debate among the Justices concerning the power of Congress to abrogate the states' Eleventh Amendment sovereign immunity using the Commerce Clause. However, the refusal of the Court to allow Tribes to sue state official using the Ex Parte Young doctrine reflects a profound disagreement with the Congressional policies enunciated in IGRA. ${ }^{201}$ As argued elsewhere, that policy revealed a congressional desire to include tribes into a

cannot be considered a direct reaction to any Supreme Court cases defining the trust duties of the United States to specific tribes. See generally, Cobell v. Norton, 240 F.3d 1081 (D.C. Cir. 2001); Cobell v. Norton, 428 F.3d 1070; and Cobell v. Kempthorne, 569 F. Supp. 2d 223 (F.D.C. 2008).

198 See Laycock \& Thomas, Interpreting the Religious Freedom Restoration Act, supra note 187.

199 Seminole Tribe v. Florida, 517 U.S. 44 (1996). See discussion, supra notes 167-171.

200 Chickasaw Nation v. United States, 534 U.S. 84 (2001).

${ }^{201}$ For a critique of that aspect of the Court's opinion, see Skibine, supra note 166 , at $297-300$. 
model of what some have termed cooperative federalism. ${ }^{202}$ Although I also noted that IGRA was different from the typical cooperative federalism statute in that it directly involved the states in the negotiation of compacts with Indian nations, ${ }^{203} \mathrm{I}$ also believed that IGRA could fit "in the concept of cooperative federalism, a concept which should be based on tri-lateral agreements between the tribes, the federal government, and the states." 204

\section{Interpreting the Alaska Native Claims Settlement Act (ANCSA).}

In Venetie, ${ }^{205}$ the Court reacted to enactment of the 1971 Alaska Native Claims Settlement Act (ANCSA) by holding that land set aside for Native Corporations under the Act was not Indian Country. Therefore, the state of Alaska could tax activities taking place on those lands. The Court achieved this surprising result twenty-seven years after ANCSA was enacted into law by insisting that lands set aside by Congress for dependent Indian communities, such as Alaskan Native Villages, could only qualify as "Indian Country" for the purpose of Section $1151,{ }^{206}$ if such lands also remained in control of the federal government. Because Native Alaskan villages held their lands in fee, the federal

202 Id. See also, id. at 285-87 ("[f]ederal statutes in the new Tribal SelfGovernance Era... have progressively adopted what could be described as a compact model.... These statutes can be seen as incorporating or integrating Indian tribes as sovereign political entities within "Our Federalism" and creating what could be called a system of federalism between the tribes and the federal government.").

203 Typical statutes embodying a cooperative federalism model include the Clean Air Act, Pub. L. 101-459, 104 Stat. 2399, the Safe Drinking Water Act, Pub. L. 99-339, 100 Stat 642, and the Clean Water Act, Pub. L. 100-4, 101 Stat 7. Indian tribes are included in the statutes and treated as States for the purpose as being able to assume primacy over the reservations' air and water resources.

${ }^{204}$ Skibine, Indian Gaming and Cooperative Federalism, supra note 166, at 287.

205 Alaska v. Vill. of Venetie, 522 U.S. 520 (1998).

206 See the language of Section 1151, supra note 147. Although 18 U.S.C. 1151 defines what lands qualify as Indian Country for the purpose of criminal jurisdiction, the definition has been applied to civil jurisdictional issues. 
government did not have complete control over such lands. Therefore, such lands could not qualify as Indian Country. ${ }^{207}$

\section{Interpreting Indian Child Welfare Act (ICWA).}

Since its enactment in 1978, the Court has only interpreted the Indian Child Welfare Act twice. From a protribal interpretation in Holyfield in $1988,{ }^{208}$ the Court came up with a very narrow interpretation of the law in Adoptive Couple v. Baby Girl in 2013. ${ }^{209}$ This new interpretation severely limited the capabilities of biological Indian fathers to invoke the protection of ICWA when intervening in adoption proceedings. The Court held that a biological father challenging the mother's decision to put the child up for adoption had to have had "custody" of his child in order to invoke the protections of ICWA.

\section{Interpreting Section 5 of the Indian Reorganization Act (IRA).}

Section 5 allows the Secretary of Interior to transfer land into trust for the benefit of Indian tribes. ${ }^{210}$ For years, the Secretary had construed that section as applying to all Indian tribes as long as such tribes were under federal jurisdiction as of the date of each land transfer. At the urging of the states, the Court in Carcieri gave a very narrow interpretation to the Indian Reorganization Act, restricting application of Section 5 to those tribes under federal jurisdiction as of $1934 .{ }^{211}$ The Court was able to reach this

207 For a critical evaluation of the Court's reasoning in Venetie, see Kristen Carpenter, Interpreting Indian Country in State of Alaska v. Native Village of Venetie, 35 Tulsa L.J. 73 (1999). See also David M. Burton, Canons of Construction, Stare Decisis, and Dependent Indian Communities: A Test of Judicial Integrity, 16 ALASKA L. REV. 37 (1998).

208 Miss. Band of Choctaw Indians v. Holyfield, 490 U.S. 20 (1989) (coming up with a national definition of "domicile" that prevented an Indian mother from avoiding application of ICWA by moving off the reservation to give birth in order to claim that her domicile was no longer on the reservation). 209 Adoptive Couple v. Baby Girl, 133 S. Ct. 2552 (2013).

210 Codified at 25 U.S.C. 5108.

211 Carcieri v. Salazar, 555 U.S. 379 (2009). 
result by surprisingly claiming that there was no ambiguity whatsoever in the statute and, therefore, Chevron deference was not applicable. ${ }^{212}$ In doing so, the Court set aside a thirtyyear-old formal regulation of the Interior Department which had interpreted the statute as only requiring that a tribe be under federal jurisdiction at the time the land was transferred into trust. ${ }^{213}$

\section{Indian Land Consolidation Act.}

As noted earlier, the Court struck down as unconstitutional parts of the Indian Land Consolidation Act twice. ${ }^{214}$ On November 27, 2017, the Court declined to revisit the Indian Land Consolidation (ILCA) when it denied cert to a petition challenging a ruling holding that ILCA allows the United States to take land into trust for a tribe even though the United States currently does not hold any land in trust for that Tribe. ${ }^{215}$ It is interesting to note that in each of the four examples cited above and this one, the Court ruled against the tribal interests. ${ }^{216}$ However, of the five statutes, only the Indian Land Consolidation Act generated a congressional response. This shows that if tribal interests are not in direct conflict with the interests of states or important non-tribal interests, Congress is ready and willing to correct Supreme

${ }^{212}$ Chevron v. N.R.D.C., 467 U.S. 837 (1984). Under Chevron, courts are supposed to give deference in interpreting an ambiguous statute to the federal agency in charge of implementing such statute as long as such agency was delegated by Congress the power to make such interpretations. ${ }^{213}$ For critical perspectives on Carcieri, see, e.g., William Wood, Indians, Tribes and "Federal" Jurisdiction, 65 U. KAN. L. REV. 415 (2016); Sarah Washburn, Comment, Distinguishing Carcieri v. Salazar: Why the Supreme Court Got It Wrong and How Congress and Courts Should Respond to Preserve Tribal and Federal Interests in the IRA's Trust-Land Provisions, 85 WASH. L. REV. 603 (2010).

214 See discussion, supra notes 176-180.

215 See Upstate Citizens for Equality v. United States, 841 F.3d 556 (2016). 216 Some may also question whether the "Supreme Court decisions in Irving and Youpee are actually anti-Indian. See, e.g., Baca, 40 Years of U.S. Supreme Court, supra note 21 (classifying the two decisions as Indian victories). 
Court decisions. The next sub-section makes this point even clearer.

\section{Interpreting the Indian Self Determination Act.}

In 1988 and 1994, Congress amended the Indian SelfDetermination Act of 1975. ${ }^{217}$ In Cherokee Nation $v$. Leavitt, ${ }^{218}$ the Supreme Court unanimously interpreted the 1988 Amendments as mandating the funding of "Contract Support Costs" associated with Self-Determination contracts entered into between the United States and the tribes. Contract support costs are "reasonable costs" that a federal agency would not have incurred, but which tribes are incurring in managing such programs. ${ }^{219}$ Even though the 1988 amendments provided that funding under the Act shall be contingent on availability of appropriations and Congress had not earmarked enough funds to cover all contract support costs, the Court reasoned that Congress had still appropriated sufficient unrestricted funds to cover the full amount of those contract support costs. Aware of this problem, Congress later enacted appropriation bills with language providing that contract support costs available to tribes should be capped at an amount "not to exceed" amounts appropriated by Congress for this activity. Yet, in Salazar v. Ramah Navajo Chapter, ${ }^{220}$ the Court, this time in a 5-4 decision, held that the United States was obligated to award each tribe the full amount of contract support costs negotiated in the previous contracts.

Unlike previous statutory interpretation cases where the Court interpreted legislation narrowly to restrict tribal rights, in this case the Court stood firmly with the tribes in upholding the contractual obligations of the United States. The Court was able to achieve this in spite of Congress's attempts to restrict tribal funding through specific language

217 P.L. 93-638, 88 Stat. 2203, codified as amended at 25 U.S.C. 450 et. seq. amended by P.L. 100-472, 102 Stat. 2285 in 1988 and further amended in 1994 by P.L. 103-413, 108 Stat. 4250.

218 Cherokee Nation v. Leavitt, 543 U.S. 631 (2005).

219 See 25 U.S.C. 450 j-1(a)(2).

220 Salazar v. Ramah Navajo, 132 S. Ct. 2181 (2012). 
in appropriation bills. In effect, the Court put the onus on Congress to amend the Indian Self-Determination Act one more time or be obligated to fund all tribal contract support costs associated with Self-Determination contracts. What accounts for the difference from other areas of statutory interpretations where the Court was not that partial to tribal interests? In may be attributed to the fact that in these two cases, neither the rights of the states nor the rights of individual non-members were at all impacted by the decisions. The cases only dealt with the tribes' contractual and financial rights vis-a-vis the federal government.

\section{The Road Not Taken}

Sometimes, congressional or judicial silence on an issue can speak as much as enacted legislation and judicial decisions. This section enumerates five key issues where tribal interests have failed to enact legislation and concludes by listing three areas where anti-tribal interests have not succeeded in motivating either Congress or the Court to act.

\section{Tribal civil jurisdiction over non- members:}

As opposed to cases involving criminal jurisdiction, none of the civil jurisdiction cases preventing tribal jurisdiction over non-members in Indian Country have been overturned. ${ }^{221}$ Congressional silence and lack of any reaction, either for or against tribal jurisdiction in this area speaks volume about either a lack of concern with such cases, or an inability to address such issues through legislation.

Although there were bills introduced in Congress at various times, for instance S. 578 in 2003, no bill was ever reported out of committee so that it could be considered on the floor of either the Senate or the House of Representatives. In the case of S. 578, this is due in part to the overly ambitious

221 South Dakota v. Bourland, 508 U.S. 679 (1993); Strate v. A-1 Contractors, 520 U.S. 438 (1997); Atkinson Trading v. Shirley, 532 U.S. 645 (2001); Nevada v. Hicks, 533 U.S. 353 (2001); and Plains Commerce Bank v. Long Family Land \& Cattle Co., 554 U.S. 316 (2008). The tribes also lost half of Brendale v. Confederated Tribes, 492 U.S. 408 (1990). 
nature of the bill. It aimed to overturn both Oliphant, the case that had divested tribes of criminal jurisdiction over nonmembers, and the United States $v$. Montana line of cases, which divested tribes of some civil jurisdiction over nonmembers. 222 Congressional inaction here can also be explained by the fact that the non-tribal interests potentially affected by such legislation have considerable more lobbying power than the non-member Indians accused of committing crimes in Indian Country as was the case during consideration of the Duro-Fix legislation. ${ }^{223}$ Another factor that may explain the lack of congressional interest in favor of legislation re-instating tribal civil jurisdiction over non-members is the fact that in many of these tribal civil jurisdiction cases, the tribal court plaintiff can also bring the lawsuit against the non-tribal person in a state or federal court. Certainly, that fact was part of the Supreme Court decision in Strate v. A-1 Contractors, ${ }^{224}$ when it concluded its opinion by stating "Gisela Fredericks may pursue her case against A-1 Contractors and Stockert in the state forum open to all who sustain injuries on North Dakota's highway. Opening the Tribal Court for her optional use is not necessary to protect tribal self-government; and requiring $\mathrm{A}-1$ and Stockert to defend against this commonplace state highway accident claim in an unfamiliar court is not crucial to "the political integrity, the economic security, or the health or welfare of the tribe." 225

In a recent article, Berger proposed three reasons explaining the Court's anti-tribal bias. First, the Justices are unfamiliar with how tribal governments operate. Secondly, the Justices are concerned that non-members are not fully protected by the United States Constitution when appearing in tribal courts. Finally, the Court does not see Indian nations as truly sovereign governments in charge of governing their

${ }^{222}$ For an examination of how this legislation came about and why it failed, see Dewi Ioan Ball, The Erosion of Tribal Power, The Supreme Court's Silent Revolution, 149-69 (University of Oklahoma Press 2016).

223 See discussion, supra notes 168-175.

224 Strate v. A-1 Contractors, 520 U.S. 438, 459 (1997).

$225 \mathrm{Id}$. at 459 . 
territories. ${ }^{226}$ The same concerns generated by unfamiliarity, lack of constitutional protections, and mixed feelings about tribal sovereignty, could also be operating at the congressional level to dim any chances of restoring tribal civil jurisdiction through legislation. However, it should be noted that although not enacted as a direct reaction to any Supreme Court case, Congress did amend some of the major environmental statutes to allow tribes to potentially be treated as States under those statutes. Such treatment would allow tribes to regulate the activities of non-members in this area. ${ }^{227}$ Perhaps any future tribal efforts in this area should focus on specific areas of civil jurisdiction instead of painting with a wider brush. ${ }^{228}$

\section{Pre-empting state tax jurisdiction in Indian Country.}

As stated earlier, 8 cases allowed states to tax activities on Indian reservations. ${ }^{229}$ The Court has allowed such taxation by either slightly modifying its Indian

226 See Berger, Hope for Indian Tribes, supra note 20, at 1914-15.

227 See the Indian Amendments to the Clean Air Act, 42 U.S.C. 7601(d)(2); the Clean Water Act, 33 U.S.C. 1377 (e); and the Safe Drinking Water Act, 42 USC 300j-11(a). See also Wisconsin v. EPA, 266 F.3d 741 (7th Cir. 2001). See Arnold W. Reitze, Jr., The Control of Air Pollution on Indian Reservations, 46 ENVTL. L. 893 (2016).

228 On the other hand, Congress has allowed some state civil jurisdiction in legislation settling tribal land claims and/or recognizing or restoring some tribes to federal recognition. See, e.g., The Wampanoag Indian Claims Settlement Act of 1987, Pub. L. 100-95, 101 Stat. 704. See also the 1988 Act establishing a reservation for the Confederated Tribes of the Grand Ronde Community, Pub. L. 100-425, 102 Stat. 1594, and the Klamath Indian Tribe Restoration Act of 1986, Pub. L. 99-393, 100 Stat. 849.

229 See Cotton Petroleum v. New Mexico, 490 U.S. 163 (1989); Dep't of Taxation v. Milhelm, 512 U.S. 679 (1994); Montana v. Crow Tribe, 523 U.S. 696 (1998); Ariz. Dep't of Revenue v. Blaze Constr., 526 U.S. 32 (1999); City of Sherrill v. Oneida Indian Nation, 544 U.S. 197 (2005); Wagnon v. Prairie Band Potawatomi Nation, 546 U.S. 95 (2005); Cty. of Yakima v. Confederated Tribes, 502 U.S. 251 (1992); and Cass County v. Leech Lake Band, 524 U.S. 103 (1998). 
preemption analysis, ${ }^{230}$ or finding that the imposition of the tax did not actually occur in Indian Country. ${ }^{231}$ In all these cases, the Court allowed state taxation by finding that the legal incidence of the tax did not fall on the Indian tribes. Furthermore, in City of Sherrill v. Oneida Indian Nation, ${ }^{232}$ the Court invoked the doctrine of laches to prevent the Tribe from challenging a State tax because a successful challenge would otherwise upset the long held and legitimate expectations of non-Indians. ${ }^{233}$ The lack of legislative activity here indicates that once the Supreme Court rules in favor of state taxation and against tribal interests in this area, such rulings are irreversible through legislation.

\section{Enacting a Seminole fix.}

Legislation is needed to resolve the problems and imbalance created by Seminole Tribe $v$. Florida. ${ }^{234}$ In Seminole Tribe, the Court struck down a section of IGRA allowing the tribes to sue states in federal court for failure to negotiate a tribal state gaming compact in good faith as unconstitutional. The Court held that Congress could not use its Commerce Clause powers to abrogate the states' sovereign immunity guaranteed by the Eleventh Amendment. Seminole Tribe being a constitutional decision, Congress cannot just overturn it. One unresolved question is whether the Secretary of the Interior can issue Class III gaming procedures upon being petitioned to do so by a tribe whose lawsuit against a state was dismissed on account of sovereign immunity. Two circuit courts have ruled that the Secretary cannot issue such regulations. ${ }^{235}$ In spite of recommendations by many

230 See, e.g., Cotton Petroleum v. New Mexico, 490 U.S. 163 (1988); Dep't of Taxation v. Milhelm, 512 U.S. 61 (1994). For a critical analysis, see Skibine, supra note 96, at 428-30.

231 See Wagnon v. Prairie Band of Potawatomi, 546 U.S. 95 (2005).

232 City of Sherrill v. Oneida Indian Nation, 544 U.S. 197 (2005).

${ }^{233}$ For a critical analysis of the decision, see Joseph William Singer, NineTenths of the Law: Title, Possession, and Sacred Obligations, 38 ConN. L. REV. 605 (2006).

${ }^{234}$ Seminole Tribe v. Florida, 517 U.S. 44 (1996).

235 See New Mexico v. Dep't of Interior, 854 F.3d 1207 (10th Cir. 2017); Texas

v. United States, 497 F.3d 491 (5th Cir. 2007). For a critique of the Texas 
scholars, no amendment to IGRA on this issue or others seem to be forthcoming. ${ }^{236}$

\section{Recognizing Native Hawaiians.}

Although so far, Native Hawaiians lost both Supreme Court cases affecting their interests, ${ }^{237}$ Congress tried but was unable to enact any kind of legislation recognizing Native Hawaiians as an indigenous/tribal governmental entity. ${ }^{238}$ However, on September 29, 2015, President Obama's administration, through the Department of the Interior, announced that it was amending regulations that had prohibited Native Hawaiians to apply for federal recognition as an Indian tribe. The new regulations would allow Native Hawaiians to petition the government for recognition as an Indian tribe. ${ }^{239}$ This may moot any further legislative activity in this area for some times.

\section{Overturning Carcieri v. Salazar. ${ }^{240}$}

So far, tribal efforts to enact a Carcieri Fix have been unsuccessful. Under Carcieri, in order to be eligible to receive land into trust under Section 5 of the Indian Reorganization Act, a tribe had to be under federal jurisdiction as of $1934 .{ }^{241}$

decision, see Skibine, supra note 166, at 293-96. See also Note, A Pretty Smart Answer: Justifying the Secretary of Interior's Seminole Fix for the Indian Gaming Regulatory Act, 40 AM. IND. L. REV. 325 (2015-2016).

236 See, e.g., Matthew L.M. Fletcher, Bringing Balance to Indian Gaming, 44 HARV. J. ON LEG. 39 (2007) (Recommending Amendments to IGRA).

237 Rice v. Cayetano, 528 U.S. 495 (2000); Hawaii v. Office of Haw. Affairs, 556 U.S. 163 (2009).

238 For a description of such legislative efforts, see Note, The Akaka Bill: The Native Hawaiians Race for Federal Recognition, 23 U. HAWAII L. REV. 857 (2001).

239 See Department of the Interior Press Release, Interior Proposes Reestablishing Government to Government Relationship with Native Hawaiian Community, Sept. 29, 2015.

${ }^{240}$ Carcieri v. Salazar, 555 U.S. 379 (2009).

${ }^{241}$ For an argument that most if not all Indian Tribes were under federal Jurisdiction as of 1934, see William Wood, Indians, Tribes, and (Federal) Jurisdiction, 65 U. KANSAS L. REV. 415 (2016). 
It should be noted, however, that Indian Nations may not be united in the effort to overturn the decision. ${ }^{242}$

\section{Repealing Section 5 of the Indian Reorganization Act (IRA) or declaring it unconstitutional.}

On the other hand, in spite of concerted efforts by the States to challenge implementation of Section 5 of the IRA, ${ }^{243}$ or declare the section unconstitutional, ${ }^{244}$ the Court never came close to holding the Section unconstitutional. ${ }^{245}$ The Court did grant cert in Department of the Interior $v$. South Dakota, ${ }^{246}$ but proceeded on remanding the case for reconsideration to the Secretary of the Interior without writing a substantial opinion. Congress on the other hand, did amend the Indian Reorganization Act in 1988 to allow tribes that had initially rejected the Act to be able to benefit from Section 5. ${ }^{247}$

\section{Abrogating tribal Sovereign Immunity}

${ }^{242}$ For background on the issues raised by the taking of land into trust for the benefit of Indian tribes pursuant to Section 5, see Note, Beyond the Carcieri Fix: The Need for Broader Reform of the Land into Trust Process of the Indian Reorganization Act of 1934, 96 IowA L. REV. 1377 (2011).

${ }^{243}$ For a critique of the implementation of Section 5, see Note, Extreme Rubber Stamping: The Fee to Trust Process under the Indian Reorganization Act of 1934, 40 PEPP. L. REV. 251 (2014).

244 See, e.g., City of Roseville v. Norton, 348 F.3d 1020 (D.C. Cir. 2003). Section 5 has been attacked as being unconstitutional as an overbroad delegation of power to the Secretary of the Interior. It has also been attacked as a violation of the Tenth Amendment to the U.S. Constitution. The Tenth Amendment provides that all powers not delegated to the Congress are reserved to the States.

245 On November 27, 2017, the Supreme Court denied cert to two petitions asking the Supreme Court to review the constitutionality of Section 5 of the IRA, 25 U.S.C. 5108, (formerly cited as 25 U.S.C. 465). See Town of Vernon v. United States, Docket No-17-8, and Upstate Citizen for Equality v. United States, Docket No. 16-1320).

246 Department of the Interior v. South Dakota, 117 S. Ct. 286 (1996).

247 The amendments to Section 5 of the IRA, codified at 25 U.S.C. 2202, were contained in Title II of the Indian Land Consolidation Act, 96 Stat 2517. 
In Kiowa Tribe v. Manufacturing Technologies, ${ }^{248}$ the Court strongly implied that Congress should consider restricting the scope of tribal sovereign immunity. ${ }^{249}$ Yet, after considering the issue in connection with enactment of the Indian Tribal Economic Development and Contracts Encouragement Act of 2000, ${ }^{250}$ Congress opted against any major revisions to the doctrine. ${ }^{251}$ It has to be noted, however, that the Court's unquestioned support for tribal sovereign immunity has been waning: From a 6-3 majority in Kiowa Tribe in 1998 to a 5-4 decision in the 2014 Bay Mills decision. ${ }^{252}$ Furthermore, the Court granted cert in Upper Skagit Indian Tribe v. Lundgren. ${ }^{253}$ In that case, the state of Washington's Supreme Court held that the Upper Skagit Indian Tribe could not rely on its sovereign immunity in a case where Plaintiffs, relying on adverse possession, had filed an in rem action against the Tribe asking a court to determine

248 Kiowa Tribe v. Mfg. Techs., 523 U.S. 751, 758 (1998).

${ }^{249} \mathrm{Id}$. at 758 ("There are reasons to doubt the wisdom of perpetuating the doctrine... In our interdependent and mobile society, however, tribal immunity extends beyond what is needed to safeguard tribal selfgovernance. This is evident when tribes take part in the Nation's commerce. Tribal enterprises now include ski resorts, gambling, and sales of cigarettes to non-Indians. In this economic context, immunity can harm those who are unaware that they are dealing with a tribe, who do not know of tribal immunity, or who have no choice in the matter, as in the case of tort victims. These considerations might suggest a need to abrogate tribal immunity, at least as an overarching rule ... we defer to the role Congress may wish to exercise in this important judgment."). For a critical look at statements made in the opinion, see William Wood, It was not an accident: The Tribal Sovereign Immunity Story, 62 AM U. L. REV. 1587 (2013).

250 P.L. 106-179, 114 Stat. 46 (2000) (amending 25 U.S.C. 81). See Andrea M. Seielstad, The Recognition and Evolution of Tribal Sovereign Immunity under Federal Law: Legal, Historical, and Normative Reflections on a Fundamental Aspect of American Indian Sovereignty, 37 TULSA L. REV. 661, 711 (2002) (summarizing congressional considerations in amending the law of tribal immunity).

251 See H.R. Rep. No. 106-501 (2000); S. Rep No. 106-150 (1999). See also Katherine Florey, Sovereign Immunity's Penumbras: Common Law, "Accident," and Policy in the Development of Sovereign Immunity Doctrine, 43 WAKE FOREST L. REV. 765, 826 (2008) (summarizing the arguments for and against the doctrine).

252 Michigan v. Bay Mills Indian Cmty., 124 U.S. 2024 (2014).

253 Doc. No. 17-387, Petition granted December 8, 2017. 
title to a disputed parcel of land. ${ }^{254}$ The United States Supreme Court could arguably just expand on language in one of its previous federal Indian law opinion allegedly indicting that tribes cannot invoke their sovereign immunity in in rem actions. ${ }^{255}$ It would be somewhat surprising, however, for the Court to have granted cert in such a relatively unimportant case just to affirm the state court on this narrow ground.

\section{Amending the Indian Child Welfare Act (ICWA) or declaring it unconstitutional.}

Anti-ICWA interest groups efforts to amend the Indian Child Welfare Act (ICWA), 256 have also gone nowhere, legislatively speaking. Although bills to amend ICWA have been introduced, so far Congress has not enacted any new amendments to this legislation. ${ }^{257}$ On the same subject, even though many have and continue to challenge some sections of ICWA as being unconstitutional, ${ }^{258}$ the Supreme Court has never granted cert to any such cases. ${ }^{259}$ However, it should be noted that in Adoptive Couple v. Baby Girl, ${ }^{260}$ the Court stated that parts of the ICWA would raise equal protection issues if

${ }^{254}$ Lundgren v. Upper Skagit Indian Tribe, 389 P.3d 569 (2017). As stated by the Supreme Court of Washington: "The Supreme Court held that the Indian General Allotment Act allowed Yakima County to impose ad valorem taxes on reservation land. The Court reached that conclusion by characterizing the county's assertion of jurisdiction over the land as in rem, rather than an assertion of in personam jurisdiction over the Yakama Nation. In other words, the Court had jurisdiction to tax on the basis of alienability of the allotted lands, and not on the basis of jurisdiction over tribal owners." Id. at 573.

255 See Yakima v. Confederated Tribes \& Bands of Yakima Indian Nation, 502 U.S. 251 (1992).

256 Pub. Law 95-608, codified at 25 U.S.C. sections 1901-1923 (2000).

257 See Barbara Ann Atwood, Flashpoints under the Indian Child Welfare Act, Toward a New Understanding of State Court Resistance, 51 EMORY L.J. 587 (2002) (discussing the major controversies regarding ICWA).

258 For a summary of current cases, see Matthew Newman and Kathryn Fort, Legal Challenges to ICWA: An Analysis of Current Case Law, 36 NO.1 Child L. Prac. 13 (2017).

259 On October 30, 2017, the Court denied cert to a case raising equal protection and due process issues. See S.S. v. Colo. River Indian Tribes, Docket No. 17-95, Petition for Cert, filed on July 17, 2017.

260 Missouri v. McNeely, 569 U.S. 141 (2013). 
the interpretation of the South Carolina Supreme Court was upheld. ${ }^{261}$

$$
* * *
$$

Tribal interests have been more adept at preventing anti-tribal bills from being enacted into law. Thus, major pieces of pro-tribal legislation like the IRA, IGRA, and ICWA have not been amended in ways adverse to tribal interests. However, the same thing could be said of anti-tribal interests' capabilities to stymie pro-tribal legislation. It is telling that Congress was able to revisit the Indian Land Consolidation Act three times and has made numerous amendments to the Indian Self Determination Act, yet tribal legislative efforts to fix IGRA in the wake of Seminole Tribe, reaffirm tribal civil jurisdiction over non-members, or preempt state taxation in Indian Country, have all been stalled.

The record confirms that it is much easier to kill rather than enact legislation. ${ }^{262}$ Many have written about congressional gridlock and the Court is, of course, aware of this phenomenon. ${ }^{263}$ The next section of this Article argues that this awareness has emboldened the Court to use judgemade law to promote its own agenda and policies in Indian Country without any fears of upsetting any equilibrium that could or should have been reached with Congress.

\section{Looking for A Different Kind of Equilibrium Through the Use of Federal Common Law.}

As stated earlier, the Court uses federal common law more than any other type of law in its Indian law jurisprudence. ${ }^{264}$ Moreover, the Court's most active use of federal common law is to protect non-members from tribal jurisdiction and promote state jurisdiction inside Indian

${ }^{261} \mathrm{Id}$. at 2565.

262 See William N. Eskridge, Vetogates, Cheuron, Preemption, 83 Notre DAME L. REV. 1441 (2008).

${ }^{263}$ See Michael J. Teter, Congressional Gridlock's Threat to Separation of Power, 2013 Wisc. L. REV. 1097 (2013); Michael, J. Gerhardt, Why Gridlock Matters, 88 Notre Dame L. Rev. 2107 (2013); Michael J. Teter, Gridlock, Legislative Supremacy, and the Problem of Arbitrary Inaction, 88 NoTRE DAME L. REV. 2217 (2013).

264 See discussion, supra notes 89-104. 
reservations. This section posits that rather than seeking to achieve equilibrium with Congress, the Court is using federal common law to impose its own version of what the equilibrium between tribal and non-tribal interests should look like.

The Court's inordinate reliance on federal common law for these purposes shows that the Court does not believe that Congress can be counted on to protect the interests of nonmembers or states in Indian Country. ${ }^{265}$ In a non-federal Indian law context, scholars have noted that the Court's desire to protect norms of federalism was based on a belief that Congress does not always have the states' interest foremost in mind when enacting legislation. ${ }^{266}$ Although there is no data supporting the ineffectiveness of Congress to look after the interests of states and non-members in Indian Country, there is legislative gridlock generally speaking. ${ }^{267}$ Therefore it would not be surprising for the Court to conclude that this gridlock may extend to controversial issues in Indian Country.

This perceived inability or unwillingness of Congress to protect the interests of states and non-members has pushed the Court to reverse certain common law presumptions that used to govern the field of Indian affairs. For instance, Frickey asserted that the Court was undermining tribal sovereignty by abandoning the exceptionalism of John Marshall's foundational Indian law cases, 268 and adopting instead a new "federal common law" for what he called, "our age of colonialism." 269 In the Handbook of Federal Indian Law, first published in 1942, Felix Cohen articulated the generally accepted paradigm defining the powers of Indian tribes before 1978. ${ }^{270}$ There, he wrote:

\footnotetext{
265 As stated by the late Philip Frickey: "it seems plain that the trend has been motivated by a judicial sense that Congress has failed to step in and fix a myriad of festering local problems by eliminating tribal authority." Philip P. Frickey, (Native) American Exceptionalism in Federal Public Law, 119 HARV. L. REV. 433, 460-61. (2005).

266 See Ruth Colker \& James Brudney, Dissing Congress, 100 MicH. L. REV. 80 (2001).

267 See discussion, supra note 257.

268 See Frickey, Native American Exceptionalism, supra note 265.

269 Frickey, Our Age of Colonialism, supra note 26.

${ }^{270}$ Cohen, supra note 9.
} 
The whole course of judicial decisions on the nature of Indian tribal powers is marked by adherence to three fundamental principles: (1) An Indian tribe possesses . . . all the powers of any sovereign state. (2) Conquest renders the tribe subject to the legislative power of the United States and, in substance, terminates the external powers of sovereignty of the tribe . . . but does not by itself affect the internal sovereignty of the tribe, i.e. its powers of local self- government. (3) These powers are subject to quantification by treaties and by express legislation of Congress. ${ }^{271}$

I have argued elsewhere that during the Rehnquist years, the Court adopted a "dependency" paradigm for the incorporation of tribes into the federalist system. ${ }^{272}$ Under that paradigm, tribes were not being incorporated under a third sphere of sovereignty but were "dependent" on Congress for all their political rights. In other words, the Court's jurisprudence was evolving towards a position that would require the existence of tribal power to be somehow confirmed in treaties or legislation. ${ }^{273}$ In addition, the Court was moving towards a position requiring congressional intent to preempt state jurisdiction in Indian country to be clearly indicated. ${ }^{274}$ Thus, instead of looking for Congress to act affirmatively to protect states and non-member interests, the Court was putting the burden on Congress to confirm tribal power and clearly establish its intent to pre-empt state jurisdiction in Indian Country.

Although Congress has adopted broad policies favoring tribal self-government, the Court's effort to impose its own agenda through federal common law has been facilitated by the fact that Congress has rarely addressed general conflicts involving tribal and state claims to power on Indian

${ }^{271} I d$. at 132 (internal citation omitted).

272 See Skibine, Beyond the Dependency Paradigm, supra note 17.

273 Id. at 668 .

${ }^{274} I d$. 
reservations. ${ }^{275}$ This lack of precise congressional direction on state taxation and tribal civil jurisdiction over non-members has enabled the Court, through the use of formalism, to formulate rigid rules from old cases in order to justify its decisions favoring States rights and disallowing tribal jurisdiction over non-members. ${ }^{276}$ The typical formalist analysis uses a "rule" derived from authoritative text. Functionalism, on the other hand, applies "standards" to resolve a given conflict. ${ }^{277}$ The use of formalism instead of functionalism has enabled the Court to hide its policy choices behind such rigid rules. Using a functional approach in federal Indian law would at least force the Court to explain why its holdings are congruent with current congressional policies. ${ }^{278}$

The Court's decision in United States v. Lara was an important milestone. ${ }^{279}$ Because it held that the Court's decisions implicitly divesting Indian tribes of sovereignty could be legislatively overturned, Lara enabled Congress to reassert its primary role in governing Indian affairs. ${ }^{280}$ As shown in the previous section, however, the Court also knows that the chances of Congress reacting to anti-tribal decisions favoring States' rights or the right of powerful non-tribal interests, are extremely small. Therefore, the Court must feel it can use federal common law to divest tribes of jurisdiction over non-members and allow state tax jurisdiction in Indian Country without the fear of being rebuffed by Congress.

275 The most notable recent exception is the Indian Gaming Regulatory Act of 1988. See discussion, supra notes 160-165.

276 See Skibine, Formalism and Judicial Supremacy, supra note 96.

277 See, e.g., William N. Eskridge Jr., Relationship Between Formalism and Functionalism in Separation of Powers Cases, 22 HARV. J. L \& PUB. POL'Y 21 (1998).

278 Skibine, Formalism and Judicial Supremacy, supra note 96, at 395.

279 United States v. Lara, 541 U.S. 193 (2004).

280 As I argued elsewhere, Lara also modified the Implicit divestiture doctrine enunciated in Oliphant and Montana when the Court stated that Indian tribes implicit loss of inherent powers was due to "restrictions... that the political branches had imposed on the tribes' exercise of inherent... power." 541 U.S. 193, 200 (2004). See Alex Tallchief Skibine. Constitutionalism, Federal Common Law, and the Inherent Powers of Indian Tribes, 39 AM. IND. L. REV. 77, 83-85 (2014-15). 
This Article takes no issue with the right of the Court to use federal common law, however the more difficult question is whether the Court's formulation of its common law rules is legitimate. Although there are very few limits, if any, on the power of federal courts to devise rules of federal common law, ${ }^{281}$ the fashioning of rules of decision should be, in one way or another, tied either to congressional policies, ${ }^{282}$ or to values emanating from the Constitution. ${ }^{283}$ As the Court noted, statutes establish policies that:

become itself a part of our law, to be given its appropriate weight not only in matters of statutory construction but also in those of decisional law...This appreciation of the broader role played by legislation in the development of the law reflects the practices of common law courts from the most ancient times. As Professor Landis has said "much of what is ordinarily regarded as 'common law' finds its sources in legislative enactment. ${ }^{284}$

Commenting on the Court's use of federal common Law, Frickey once stated that the "unstated assumption" underlying these federal common law cases was that even though Congress has not spoken on the issues being decided, the Court is presuming that it is merely following the "wishes

281 See Louise Weinberg, Federal Common Law, 83 Nw. U. L. REV. 805 (1989) ("I take it then that there are no fundamental constraints on the fashioning of federal rules of decision.")

282 See Fletcher, Federal Indian Policy, supra note 15, at 168-82 (advocating a "consistent-with federal-policy" test for deciding some federal Common law Indian cases such as cases divesting tribes of sovereignty and cases enlarging state jurisdiction in Indian Country).

283 See, e.g., Bradford R. Clark, Federal Common Law: A structural Reinterpretation, 144 U. PA. L. REV. 124 (1996)(arguing that courts should be able to make rules of federal common law only if they are directly implied from the constitutional structure or if they are necessary to further a basic structure of the constitutional scheme).

284 Moragne v. State Marine Lines, 398 U.S. 375, 390-91, 393 (1970) (quoting James Landis, Statutes and the Sources of Law," Harvard Legal Essays, 213-14 (1934)). 
of Congress." 285 Frickey concluded, however, that there was no evidence supporting such a judicial presumption. ${ }^{286}$ Other scholars have noted that when it comes to federal Indian common law, the decisional law is divorced from current congressional policies. ${ }^{287}$ As stated by Frank Pommersheim, "[i]n a sense, the Court has become the ultimate organ for formulating Indian policy in contemporary law. This raises a quintessential separation of powers issue, with the Court usurping the constitutional role of Congress to make law and formulate policy." 288 Some scholars have agreed. ${ }^{289}$ Others have argued that whether Indian nations have maintained sovereign powers over non-members should be treated as a political question. ${ }^{290}$

Native Americans have been described at various times as the "forgotten Americans," or the "vanishing Indians." 291 There was a time when almost all Indian tribes were economically powerless and had very little or no impact on the political and economic life of the United States. These times are over: whether it is because of the success of Indian casino gaming, 292 or other aspects of tribal economic development, 293 Indian issues are no longer on the

\footnotetext{
285 Frickey, Our Age of Colonialism, supra note 26, at 7.

${ }^{286} I d$.

287 See Fletcher, Federal Indian Policy, supra note 15.

288 Frank Pommersheim, Broken Landscape: Indians Tribes, And THE Constitution 229 (2009).

289 See Lance Sorenson, Tribal Sovereignty and the Recognition Power (Nov. 6, 2017), available at SSRN.com/abstract=3066221. (suggesting that the Court's use of Federal Common Law to find implicit divestiture of tribal sovereignty is unconstitutional as a violation of the Separation of Power principle.)

290 See Michalyn Steele, Plenary Power, Political Questions, and Sovereignty in Indian Affairs, 63 U.C.L.A. L. REV. 666 (2016).

291 See Fort, The Vanishing Indian Returns, supra note 13.

292 See generally, Skibine, Indian Gaming and Cooperative Federalism, supra note 166.

${ }^{293}$ On tribal economic development, see Robert J. Miller, American Indian Entrepreneurs: Unique Challenges. Unlimited Potential, 40 ARIZ. SR. L. J. 1297 (2008); W Greg Guedel \& J.D. Colbert, Capital Inequality, and Self Determination: Creating a Sovereign Financial System for Native American Nations, 41 AM. IND. L. REV. 1 (2016).
} 
backburner. ${ }^{294}$ How Indian tribes conduct their politics and handle their business affairs matters to the non-Indian world. ${ }^{295}$ Because of this new reality, the Court has been in the process of re-adjusting the legal landscape. ${ }^{296}$ In looking for an equilibrium between tribal and non-tribal interests, the Court may be adjusting the rules to ensure that what it (subjectively) considers a level playing field between the Tribes and the states, is achieved. Controversial decisions in cases such as City of Sherrill and Plains Commerce Bank may reflect a knee jerk reaction to the Tribes' newfound political and economic power. ${ }^{297}$

A good example of the Court's desire to create a new level playing field is its recent decision in Lewis v. Clarke. ${ }^{298}$ In that case, the Court refused to extend the Tribe's sovereign immunity to a tribal employee alleged to have committed a tort while driving a tribal vehicle off the reservation but still within the scope of his employment. 299 In coming to its decision, the Court took into account whether similar state employees would have enjoyed the State's sovereign immunity in such situations. After summarizing the rules denying extension of state sovereign immunity in such circumstances, the Court stated, "There is no reason to depart from these

294 See Matthew L.M. Fletcher, Indian Tribal Business \& the OffReservation Market, 12 LEWIS \& CLARK L. REV. 1047 (2008).

295 See Angela R. Riley, Good (Native) Governance, 107 CoLUM. L. REV. 1049 (2007) (explaining why it is now more important for tribal governments to adopt good governmental practices and why tribal government should use traditional forms of governance even if those are not similar to American style governance).

296 See Judith Resnick, Dependent Sovereigns, supra note 23.

297 See discussion, supra notes 215-227.

298 Lewis v. Clarke, 137 S. Ct. 1285 (2017).

299 Id. at 1291 ("It is apparent that these general principles foreclose Clarke's sovereign immunity defense in this case. This is a negligence action arising from a tort committed by Clarke on an interstate highway within the State of Connecticut. The suit is brought against a tribal employee operating a vehicle within the scope of his employment but on state lands, and the judgment will not operate against the Tribe. This is not a suit against Clarke in his official capacity. It is simply a suit against Clarke to recover for his personal actions, which "will not require action by the sovereign or disturb the sovereign's property."). 
general rules in the context of tribal sovereign immunity." 300 That case indicates that from now on, Indian nations should be very judicious when invoking sovereign immunity. ${ }^{301}$ The more powerful the interests being affected by the use of tribal immunity are, the more likely there is to be a response from Congress. The recent transfer of patents from Allergan to the St. Regis Mohawk tribe in the hope of shielding such patents from judicial scrutiny provides a good example. ${ }^{302}$ Legislation was promptly introduced in Congress purporting to abrogate tribal sovereign immunity in such cases. ${ }^{303}$ Whether such legislation moves forward remains to be seen. ${ }^{304}$ But if I am correct about how the Court behaves when faced with congressional gridlock or inaction and the issue is important enough to the Court, it will intervene and act decisively in a manner that may not be positive for tribal interests. ${ }^{305}$

\section{CONCLUSION}

The Court's continued reliance on doctrines of federal common law to divest tribes of sovereignty or allow state jurisdiction in Indian Country is unfortunate and undermines congressional policies favoring tribal self-government and economic self-sufficiency. However, there are reasons for tribes to be somewhat optimistic. Congressional response to

${ }^{300} \mathrm{Id}$. at $1290-91$.

301 See Matthew L. M. Fletcher, Rights Without Remedies, 11 N.Y.U. J. L. \& LiBERTIEs 236, 254-56 (2017) (Examining the more controversial use of Tribal Sovereign Immunity and cautioning that more unexpected or innovative use of the doctrine may generate a congressional response.)

302 See Mylan Pharm. v. St. Regis Mohawk, decision of the Patent Trial \& Appeal Board (Feb. 23, 2018).

303 See S. 1948, introduced by United States Senator Claire McCaskill on October 10, 2017.

304 The Patent \& Appeal Board refused to recognize the tribal immunity in this case. Whether the legislation moves forward will probably depend on whether that decision is overturned on appeal.

305 Another controversial issue that may generate a judicial reaction from the Court has been the use of tribal sovereign immunity to protect payday lenders from judicial scrutiny. See Nathalie Martin \& Joshua Schwartz, The Alliance Between Payday Lenders and Tribes: Are Both Tribal Sovereignty and Consumer Protection at Risk?, 69 WASH. \& LEE L. REV. 751, 778-84 (2012). 
the Supreme Court's Indian law jurisprudence, while not overly active, has not been detrimental to tribal interests. Although enacting pro Indian pan-tribal legislation, such as the Indian Child Welfare Act or the Indian Gaming Regulatory Act, is definitely harder than it used to be, ${ }^{306}$ individual tribes have continued to be successful in enacting tribal specific legislation. ${ }^{307}$ Moreover, the overall percentage of tribal wins in the last thirty years while not great (28\%), has increased with each decade. ${ }^{308}$

In conclusion, the overall trend in the cases does indicate that the Court is now more willing to accept the position of Indian nations as the Third Sovereign within our federalist system. In a recent Supreme Court decision discussing the inherent sovereignty of Puerto Rico, Justice Kagan, writing for the Court, compared such sovereignty to the sovereignty of Indian nations and stated

Originally, this Court has noted "the tribes were self-governing sovereign political communities possessing," (among other capacities) the "inherent power to prescribe laws their members and to punish infractions of those laws.". . . After the formation of the United States, the tribes became "domestic dependent nations," subject to the plenary control of Congress. . . But unless and until Congress withdraws a tribal power-including

\footnotetext{
306 On suggesting strategies to enact pan-tribal legislation supporting tribal self-determination, see Kevin K. Washburn, Tribal Self-Determination at the Crossroads, 38 CoNN. L. REV. 777 (2006).

307 See Carlson, Congress and Indians, supra note 28, at 87 ("Congress's enactment rate for Indian-related legislation was higher than its enactment rate for legislation more generally during the time period studied. This higher enactment rate has important implications for how we understand Congress as a policymaker, its relationship with Indians, and the formulation of federal Indian law and policy.").

308 See discussion, supra notes 145-149.
} 
the power to prosecute-the Indian community

retains that authority in its earliest form. ${ }^{309}$

This language is in line with the paradigm articulated by Felix Cohen under which Indian nations have retained all their inherent sovereignty except to the extent that such sovereignty has been given up in treaties or specifically taken away by congressional legislation. ${ }^{310}$ It is also consistent with the implicit divestiture doctrine as arguably re-conceptualized by Justice Breyer in United States v. Lara, where the Court took the position that previous court decisions, that had implicitly divested tribes of some inherent powers, only did so because of the "restrictions ... that the political branches had imposed on the tribes' exercise of inherent . . power." "311 It is not consistent, however, with the implicit divestiture doctrine as conceptualized in Oliphant or Montana, where tribes had some of their sovereign powers implicitly divested upon incorporation into the United States because these powers were either inconsistent with the sovereign interests of the United States or subjectively deemed not necessary to tribal self-government. ${ }^{312}$

\section{APPENDIX A}

Key:

Type of Law Used (TLU): Federal Common Law = FCL; Statutory/Treaty interpretation = STI; Common Law/Statutory $=$ CLS; Constitutional Law $=$ Con.; Common law $=$ Com.; Statutory $=$ Stat.; Procedural $=$ Proc.; Statutory Interpretation $=$ SI; Treaty Interpretation $=\mathrm{TI}$

Substantive Rights Affected (SRA): Sovereign Rights = Sov.; Economic Rights = Econ.; Property Rights = Prop.;

309 Puerto Rico v. Sanchez Valle, 136 S. Ct. 1863, 1872 (2016) (holding that for the purposes of the double jeopardy clause, Puerto Rico did not have any inherent sovereignty separate from that of the United States.) Although there were two dissenters, only Justice Thomas objected to the quoted language. $I d$. at 1877.

310 See discussion, supra notes 263-264.

311 United States v. Lara, 541 U.S. 193, 200 (2004). See discussion, supra notes 272-273.

312 See discussion, supra notes 272-283. 
Trusts Doctrine $=$ Tru.; Cultural $/$ Religious $=\mathrm{C} / \mathrm{R}$; Sovereign $/$ Political $=$ Sov. $/$ Pol.;

$\mathrm{Win} / \mathrm{Loss}=\mathrm{W} / \mathrm{L}$

\begin{tabular}{|c|c|c|c|c|}
\hline Cases & Citation & W/L & TLU & SRA \\
\hline $\begin{array}{l}\text { Iowa Mutual } \\
\text { Ins. Co. v. } \\
\text { LaPlante }\end{array}$ & 480 U.S. 9 (1987) & Win & FCL & Sov. \\
\hline $\begin{array}{l}\text { Amoco } \\
\text { Production v. } \\
\text { Gambell } \\
\end{array}$ & 480 U.S. 531 (1987) & Loss & STI & Econ. \\
\hline Hodel v. Irving & 481 U.S. 704 (1987) & Loss & Con. & Econ. \\
\hline $\begin{array}{l}\text { United States } \\
\text { v. Cherokee } \\
\text { Nation }\end{array}$ & 480 U.S. 700 (1987) & Loss & Con. & Econ. \\
\hline $\begin{array}{l}\text { California v. } \\
\text { Cabazon Band }\end{array}$ & 480 U.S. 202 (1987) & Win & CLS & $\begin{array}{l}\text { Sov.l } \\
\text { Econ. }\end{array}$ \\
\hline $\begin{array}{l}\text { Lyng v. } \\
\text { Northwest } \\
\text { Cemetery Ass. }\end{array}$ & 485 U.S. 439 (1988) & Loss & Con. & $\mathrm{C} / \mathrm{R}$ \\
\hline $\begin{array}{l}\text { Oklahoma Tax } \\
\text { Comm. v. } \\
\text { Graham }\end{array}$ & 489 U.S. 838 (1989) & Loss & Proc. & $\begin{array}{l}\text { Not } \\
\text { Appli- } \\
\text { cable }\end{array}$ \\
\hline $\begin{array}{l}\text { Mississippi } \\
\text { Band of } \\
\text { Choctaw v. } \\
\text { Holyfield }\end{array}$ & 490 U.S. 30 (1989) & Win & STI & $\begin{array}{l}\text { Sov.l } \\
\text { Pol. }\end{array}$ \\
\hline $\begin{array}{l}\text { Cotton } \\
\text { Petroleum v. } \\
\text { New Mexico } \\
\end{array}$ & 490 U.S. 163 (1989) & Loss & FCL & $\begin{array}{l}\text { Sov./ } \\
\text { Pol. }\end{array}$ \\
\hline Duro v. Reina & 495 U.S. 676 (1990) & Loss & FCL & $\begin{array}{l}\text { Sov./ } \\
\text { Pol. }\end{array}$ \\
\hline $\begin{array}{l}\text { Brendale v. } \\
\text { Confederated } \\
\text { Tribes }\end{array}$ & 492 U.S. 408 (1990) & $\begin{array}{l}\text { Win } \\
\text { and } \\
\text { Loss }\end{array}$ & FCL & $\begin{array}{l}\text { Sov./ } \\
\text { Pol. }\end{array}$ \\
\hline $\begin{array}{l}\text { Employment } \\
\text { Division v. } \\
\text { Smith }\end{array}$ & 494 U.S. 872 (1990) & Loss & Con. & $\mathrm{C} / \mathrm{R}$ \\
\hline
\end{tabular}




\begin{tabular}{|c|c|c|c|c|}
\hline $\begin{array}{l}\text { Oklahoma Tax } \\
\text { Comm. v. } \\
\text { Citizen Band }\end{array}$ & 498 U.S. 505 (1991) & Win & Com. & $\begin{array}{l}\text { Sov./ } \\
\text { Pol. }\end{array}$ \\
\hline $\begin{array}{l}\text { Blatchford v. } \\
\text { Native Village } \\
\text { of Noatak }\end{array}$ & 501 U.S. 775 (1991) & Loss & Con. & $\begin{array}{l}\text { Sov./ } \\
\text { Pol. }\end{array}$ \\
\hline $\begin{array}{l}\text { County of } \\
\text { Yakima v. } \\
\text { Confederated } \\
\text { Tribes }\end{array}$ & 502 U.S. 251 (1992) & Loss & STI & $\begin{array}{l}\text { Sov./ } \\
\text { Pol. }\end{array}$ \\
\hline $\begin{array}{l}\text { Oklahoma Tax } \\
\text { Comm. v. Sac } \\
\text { \& Fox }\end{array}$ & 508 U.S. 114 (1993) & Win & Com. & $\begin{array}{l}\text { Sov./ } \\
\text { Pol. }\end{array}$ \\
\hline $\begin{array}{l}\text { South Dakota } \\
\text { v. Bourland }\end{array}$ & 508 U.S. 679 (1993) & Loss & Com. & $\begin{array}{l}\text { Sov./ } \\
\text { Pol. }\end{array}$ \\
\hline $\begin{array}{l}\text { Negonsott v. } \\
\text { Samuels }\end{array}$ & 507 U.S. 99 (1993) & Loss & STI & $\begin{array}{l}\text { Sov./ } \\
\text { Pol. }\end{array}$ \\
\hline Lincoln v. Vigil & 508 U.S. 182 (1993) & Loss & Proc. & N/A \\
\hline Hagen v. Utah & 510 U.S. 399 (1994) & Loss & STI & $\begin{array}{l}\text { Sov./ } \\
\text { Pol. }\end{array}$ \\
\hline $\begin{array}{l}\text { Dept. of } \\
\text { Taxation v. } \\
\text { Milhelm } \\
\end{array}$ & 512 U.S. 679 (1994) & Loss & Com. & $\begin{array}{l}\text { Sov./ } \\
\text { Pol. }\end{array}$ \\
\hline $\begin{array}{l}\text { Ok.Tax Comm. } \\
\text { V. Chickasaw } \\
\text { Nation }\end{array}$ & 515 U.S. 450 (1995) & Win & Com. & $\begin{array}{l}\text { Sov./ } \\
\text { Pol. }\end{array}$ \\
\hline $\begin{array}{l}\text { Seminole Tribe } \\
\text { v. Florida }\end{array}$ & 517 U.S. 44 (1996) & Loss & Con. & $\begin{array}{l}\text { Sov./ } \\
\text { Pol. }\end{array}$ \\
\hline $\begin{array}{l}\text { Strate v. A-1 } \\
\text { Contractors }\end{array}$ & 520 U.S. 438 (1997) & Loss & Com. & $\begin{array}{l}\text { Sov./ } \\
\text { Pol. }\end{array}$ \\
\hline $\begin{array}{l}\text { Babbitt v. } \\
\text { Youpee }\end{array}$ & 519 U.S. 234 (1997) & Loss & Con. & Econ. \\
\hline $\begin{array}{l}\text { Idaho v. Coeur } \\
\text { D'Alene }\end{array}$ & 521 U.S. 261 (1997) & Loss & $\mathrm{SI}$ & $\begin{array}{l}\text { Sov./ } \\
\text { Pol. }\end{array}$ \\
\hline $\begin{array}{l}\text { Alaska v. } \\
\text { Village of } \\
\text { Venetie } \\
\end{array}$ & 522 U.S. 520 (1998) & Loss & SI & $\begin{array}{l}\text { Sov./ } \\
\text { Pol. }\end{array}$ \\
\hline
\end{tabular}




\begin{tabular}{|c|c|c|c|c|}
\hline $\begin{array}{l}\text { Cass County v. } \\
\text { Leech Lake } \\
\text { Band }\end{array}$ & 524 U.S. 103 (1998) & Loss & SI & $\begin{array}{l}\text { Sov./ } \\
\text { Pol. }\end{array}$ \\
\hline $\begin{array}{l}\text { South Dakota } \\
\text { v. Yankton } \\
\text { Sioux Tribe } \\
\end{array}$ & 522 U.S. 329 (1998) & Loss & SI & $\begin{array}{l}\text { Sov./ } \\
\text { Pol. }\end{array}$ \\
\hline $\begin{array}{l}\text { Montana v. } \\
\text { Crow Tribe }\end{array}$ & 523 U.S. 696 (1998) & Loss & Com. & $\begin{array}{l}\text { Sov./ } \\
\text { Pol. }\end{array}$ \\
\hline $\begin{array}{l}\text { Kiowa Tribe v. } \\
\text { Manufacturing } \\
\text { Technologies }\end{array}$ & 523 U.S. 751 (1998) & Win & Com. & $\begin{array}{l}\text { Sov./ } \\
\text { Pol. }\end{array}$ \\
\hline $\begin{array}{l}\text { Arizona Dept. } \\
\text { of Revenue v. } \\
\text { Blaze }\end{array}$ & 526 U.S. 32 (1999) & Loss & Com. & $\begin{array}{l}\text { Sov./ } \\
\text { Pol. }\end{array}$ \\
\hline $\begin{array}{l}\text { Minnesota v. } \\
\text { Mille Lacs } \\
\text { Band of } \\
\text { Chippewa }\end{array}$ & 526 U.S. 172 (1999) & Win & $\mathrm{TI}$ & $\begin{array}{l}\text { Econ./ } \\
\text { Prop. }\end{array}$ \\
\hline $\begin{array}{l}\text { El Paso } \\
\text { Natural Gas v. } \\
\text { Neztsosie }\end{array}$ & 526 U.S. 473 (1999) & Loss & Stat. & $\begin{array}{l}\text { Sov./ } \\
\text { Pol. }\end{array}$ \\
\hline $\begin{array}{l}\text { Amoco } \\
\text { Production v. } \\
\text { Southern Ute } \\
\text { Tribe }\end{array}$ & 526 U.S. 865 (1999) & Loss & Stat. & $\begin{array}{l}\text { Econ./ } \\
\text { Prop. }\end{array}$ \\
\hline $\begin{array}{l}\text { Dept. of } \\
\text { Interior v. } \\
\text { Klamath River } \\
\text { Users }\end{array}$ & 532 U.S. 1 (2000) & Loss & Com. & Tru. \\
\hline $\begin{array}{l}\text { Rice v. } \\
\text { Cayetano }\end{array}$ & 528 U.S. 495 (2000) & Loss & Con. & Pol. \\
\hline $\begin{array}{l}\text { Arizona v. } \\
\text { California }\end{array}$ & 530 U.S. 392 (2000) & Win & Proc. & Prop. \\
\hline $\begin{array}{l}\text { Chickasaw } \\
\text { Nation v. } \\
\text { United States }\end{array}$ & 534 U.S. 84 (2001) & Loss & Stat. & Econ. \\
\hline $\begin{array}{l}\text { Nevada v. } \\
\text { Hicks }\end{array}$ & 533 U.S. 353 (2001) & Loss & Com. & Sov. \\
\hline
\end{tabular}




\begin{tabular}{|c|c|c|c|c|}
\hline $\begin{array}{l}\text { C\&L } \\
\text { Enterprise v. } \\
\text { Citizens Band } \\
\text { Potawatomi }\end{array}$ & 532 U.S. 422 (2001) & Loss & Com. & Sov. \\
\hline $\begin{array}{l}\text { Atkinson } \\
\text { Trading v. } \\
\text { Shirley }\end{array}$ & 532 U.S. 645 (2001) & Loss & Com. & $\begin{array}{l}\text { Sov.l } \\
\text { Pol. }\end{array}$ \\
\hline $\begin{array}{l}\text { Idaho v. } \\
\text { United States }\end{array}$ & 533 U.S 262 (2001) & Win & Stat. & Prop. \\
\hline $\begin{array}{l}\text { Inyo County v. } \\
\text { Paiute } \\
\text { Shoshone } \\
\text { Indians }\end{array}$ & 538 U.S. 701 (2003) & Loss & Stat. & Sov. \\
\hline $\begin{array}{l}\text { United States } \\
\text { v. Navajo } \\
\text { Nation I } \\
\end{array}$ & 537 U.S. 488 (2003) & Loss & Com. & Tru. \\
\hline $\begin{array}{l}\text { United States } \\
\text { v. White } \\
\text { Mountain } \\
\text { Apache }\end{array}$ & 537 U.S. 465 (2003) & Win & Com. & Tru. \\
\hline $\begin{array}{l}\text { United States } \\
\text { v. Lara }\end{array}$ & 541 U.S. 193 (2004) & Win & Con. & $\begin{array}{l}\text { Sov./ } \\
\text { Pol. }\end{array}$ \\
\hline $\begin{array}{l}\text { City of Sherrill } \\
\text { v. Oneida } \\
\text { Indian Nation }\end{array}$ & 544 U.S. 197 (2005) & Loss & Com. & $\begin{array}{l}\text { Sov./ } \\
\text { Pol. }\end{array}$ \\
\hline $\begin{array}{l}\text { Wagnon v. } \\
\text { Prairie Band } \\
\text { Potawatomi }\end{array}$ & 546 U.S. 95 (2005) & Loss & Com. & $\begin{array}{l}\text { Sov./ } \\
\text { Pol. }\end{array}$ \\
\hline $\begin{array}{l}\text { Cherokee } \\
\text { Nation v. } \\
\text { Leavitt } \\
\end{array}$ & 543 U.S. 631 (2005) & Win & Stat. & $\begin{array}{l}\text { Econ./ } \\
\text { Prop. }\end{array}$ \\
\hline $\begin{array}{l}\text { Plains } \\
\text { Commerce } \\
\text { Bank v. Long } \\
\text { Family Land }\end{array}$ & 554 U.S. 316 (2008) & Loss & Com. & $\begin{array}{l}\text { Sov./ } \\
\text { Pol. }\end{array}$ \\
\hline $\begin{array}{l}\text { Hawaii v. } \\
\text { Office of } \\
\text { Hawaiian } \\
\text { Affairs }\end{array}$ & 556 U.S. 163 (2009) & Loss & Stat. & Prop. \\
\hline
\end{tabular}




\begin{tabular}{|c|c|c|c|c|}
\hline $\begin{array}{l}\text { United States } \\
\text { v. Navajo } \\
\text { Nation II } \\
\end{array}$ & 556 U.S. 287 (2009) & Loss & Com. & Tru. \\
\hline $\begin{array}{l}\text { Carcieri v. } \\
\text { Salazar }\end{array}$ & 555 U.S. 379 (2009) & Loss & Stat. & Sov. \\
\hline $\begin{array}{l}\text { United States } \\
\text { v. Jicarilla } \\
\text { Apache Nation }\end{array}$ & 564 U.S. 162 (2011) & Loss & Com. & Tru. \\
\hline $\begin{array}{l}\text { United States } \\
\text { v. Tohono } \\
\text { O'Odham }\end{array}$ & 563 U.S. 307 (2011) & Loss & Proc. & Tru. \\
\hline $\begin{array}{l}\text { Salazar v. } \\
\text { Ramah Navajo }\end{array}$ & $\begin{array}{l}132 \text { S. Ct. } 2181 \\
(2012)\end{array}$ & Win & Stat. & $\begin{array}{l}\text { Econ./ } \\
\text { Prop. }\end{array}$ \\
\hline $\begin{array}{l}\text { Match-E-Be- } \\
\text { Nash-She- } \\
\text { Wish v. } \\
\text { Patchack }\end{array}$ & 567 U.S. 209 (2012) & Loss & Stat. & Tru. \\
\hline $\begin{array}{l}\text { Adoptive } \\
\text { Couple v. Baby } \\
\text { Girl }\end{array}$ & $\begin{array}{l}133 \text { S. Ct. } 2552 \\
(2013)\end{array}$ & Loss & Stat. & $\begin{array}{l}\text { Sov./ } \\
\text { Pol. }\end{array}$ \\
\hline $\begin{array}{l}\text { Michigan v. } \\
\text { Bay Mills } \\
\text { Indian } \\
\text { Community }\end{array}$ & $\begin{array}{l}124 \text { U.S. } 2024 \\
(2014)\end{array}$ & Win & Com. & $\begin{array}{l}\text { Sov./ } \\
\text { Pol. }\end{array}$ \\
\hline $\begin{array}{l}\text { Nebraska v. } \\
\text { Parker }\end{array}$ & $\begin{array}{l}136 \text { S. Ct. } 1072 \\
(2016)\end{array}$ & Win & Stat. & $\begin{array}{l}\text { Sov./ } \\
\text { Pol. }\end{array}$ \\
\hline $\begin{array}{l}\text { United States } \\
\text { v. Bryant }\end{array}$ & $\begin{array}{l}136 \text { S. Ct. } 1954 \\
(2016)\end{array}$ & Win & Com. & $\begin{array}{l}\text { Sov./ } \\
\text { Pol. }\end{array}$ \\
\hline $\begin{array}{l}\text { Menominee v. } \\
\text { United States }\end{array}$ & $\begin{array}{l}136 \text { S. Ct. } 750 \\
(2016)\end{array}$ & Loss & Proc. & $\begin{array}{l}\text { Econ./ } \\
\text { Prop. }\end{array}$ \\
\hline $\begin{array}{l}\text { Dollar General } \\
\text { v. Mississippi } \\
\text { Band of } \\
\text { Choctaw }\end{array}$ & $\begin{array}{l}136 \text { S. Ct. } 2159 \\
(2016)\end{array}$ & Win & Com. & $\begin{array}{l}\text { Sov./ } \\
\text { Pol. }\end{array}$ \\
\hline Lewis v. Clark & $\begin{array}{l}137 \text { S. Ct. } 1285 \\
(2017)\end{array}$ & Loss & Com. & $\begin{array}{l}\text { Sov.l } \\
\text { Pol. }\end{array}$ \\
\hline Matal v. Tam & $\begin{array}{l}\text { 137 S. Ct. } 1744 \\
(2017)\end{array}$ & Loss & Con. & $\mathrm{C} / \mathrm{R}$ \\
\hline
\end{tabular}

